\title{
Geology and palynology of the Triassic succession of Bjørnøya
}

\author{
ATLE MØRK, JORUNN OS VIGRAN AND PETER A. HOCHULI
}

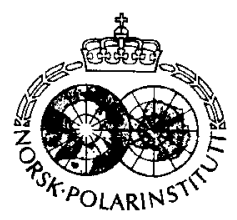

\begin{abstract}
Mørk, A., Vigran, J. O. \& Hochuli, P. A. 1990: Geology and palynology of the Triassic succession of Bjørnøya. Polar Research 8, 141-163.

The Triassic succession of Bjørnøya $(200 \mathrm{~m})$ comprises the Lower Triassic Urd Formation $(65 \mathrm{~m})$ of the Sassendalen Group, and the Middle and Upper Triassic Skuld Formation (135 $\mathrm{m}$ ) of the Kapp Toscana Group. These units are separated by a condensed ?Middle Triassic sequence represented by a phosphatic remanié conglomerate $(0.2 \mathrm{~m})$.

The Urd Formation consists of grey to dark grey shales with yellow weathering dolomitic beds and nodules. Palynology indicates the oldest beds to be Dienerian: ammonoid faunas in the middle and upper part of the formation are of Smithian age. The organic content (c. $1 \%$ ) includes kerogen of land and marine origin, reflecting a shallow marine depositional environment.

The Skuld Formation is dominated by grey shales with red weathering siderite nodules. There are minor coarsening upwards sequences: the highest hed cxposed is a $20 \mathrm{~m}$ thick, very fine-grained sandstonc. Palynomorphs indicate a late Ladinian age for the lower part of the formation, and macrofossils and palynomorphs indicate Ladinian to Carnian ages for the upper part. Sedimentary structures, a sparse marine fauna and microplankton indicate deposition in a shallow marine environment. The organic residues contain dominantly terrestrially derived kerogen.
\end{abstract}

Atle Mørk and Jorunn Os Vigran, Continental Shelf Institute (IKU), N-7034 Trondheim, Norway; Peter A. Hochuli, Esso Rep, 213 Cours Victor Hugo, B.P. 150, 33321 Bègles, CEDEX, France; A ugust 1989 (revised February 1990).

Bjørnøya, the southernmost island of the Svalbard Archipelago, is situated on the Stappen High close to the western margin of the Barents Shelf, midway between Spitsbergen and the mainland of Norway (Fig. 1). Despite its small size $\left(178 \mathrm{~km}^{2}\right)$, the island has an extensive geological succession of late Precambrian to early Mesozoic age that aids significantly the understanding and interpretation of the geology of the adjacent Barents Shelf area.

Geological study of the island began at the end of the last century, the Triassic succession was described by Andersson (1900); his fossil collection was described by Böhm (1903). Detailed mapping (Horn \& Orvin 1928, 1:50,000 geological map) gave little new information on the Triassic succession. Comments on the Triassic succession of the island were included in the regional studies of the Svalbard Archipelago by Buchan et al. (1965) and Tozer \& Parker (1968). These studies were, however, hampered by lack of new field data. A new phase of investigation of the Triassic rocks, started by Soviet geologists (Pchelina 1972; Krasilshchikov \& Livshits 1974), was continued by Norwegians (Mørk et al. 1982; Bjorøy et al. 1983; Worsley et al. in press).

\section{Geological setting}

The sedimentary succession of Bjørnøya comprises three main geological elements (Horn \& Orvin 1928) (Fig. 1):

-Triassic, c. $200 \mathrm{~m}$ of fine-grained clastics.

- Upper Devonian to Permian, c. 1,200 m of clastics and carbonates.

- Hecla Hoek basement, c. $1,200 \mathrm{~m}$ of metamorphosed clastics and carbonates.

The Hecla Hoek basement forms the mountainous southern part of Bjørnøya, and clastics and carbonates of Devonian to Permian age are exposed over most of the remainder of the island. The uppermost Permian Miseryfjellet Formation (and partly the Hambergfjellet Formation) rests with angular unconformity on earlier Permian and pre-Permian units. The Triassic rocks are present only on the highest mountain of Bjørnøya, Miseryfjellet, where they rest disconformably on the Miseryfjellet Formation. This contact is marked by a topographic break in slope (Fig. 2) that reflects the great difference in hardness of the Permian limestones and the Triassic shales.

The Devonian to Permian succession was briefly described by Worsley \& Edwards (1976) 


\section{Bjørnøya}

a. Localization

b. Geological map

c. Geology of Miseryfjellet area

d. Stratigraphical column and map symbols
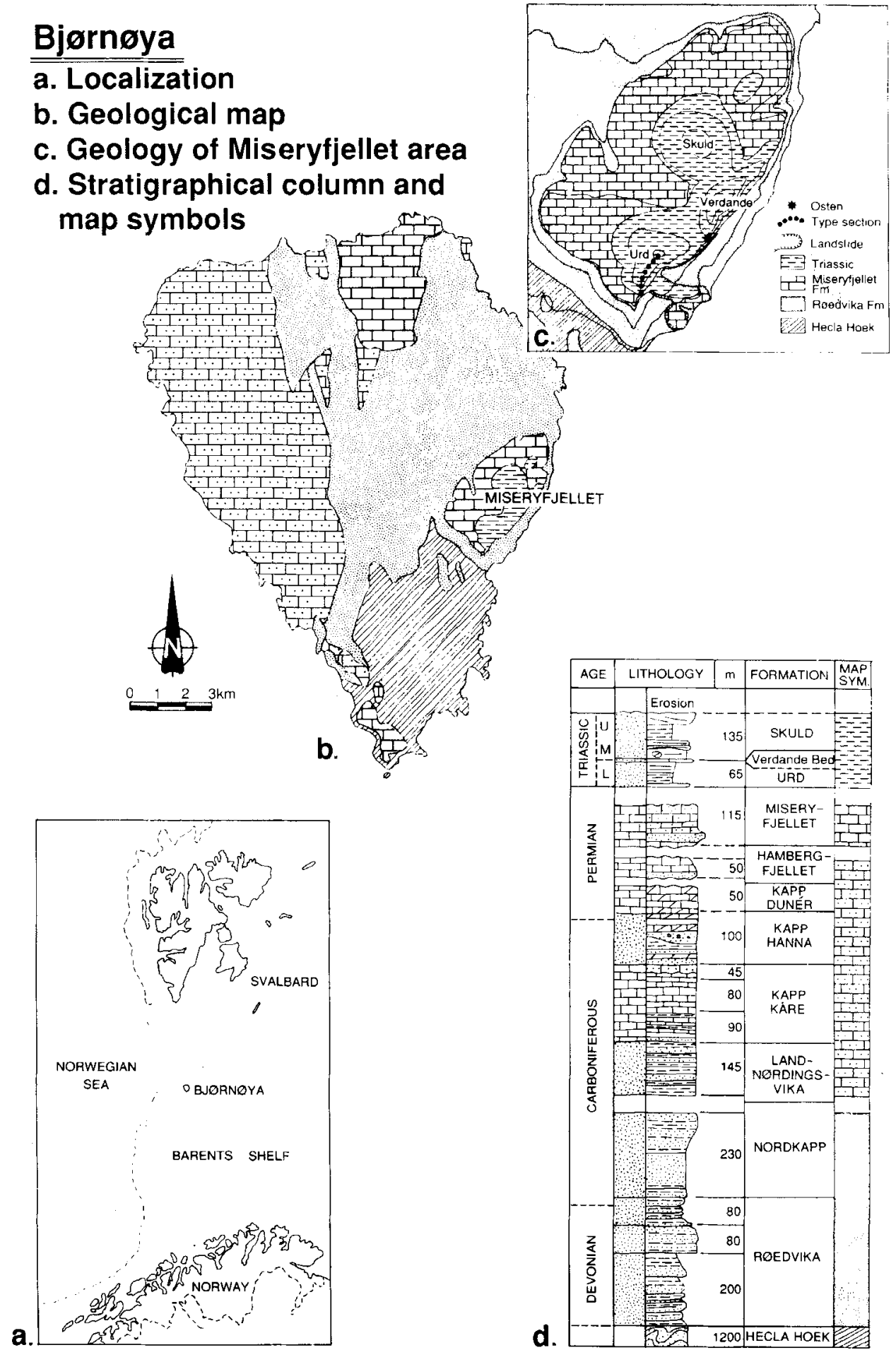


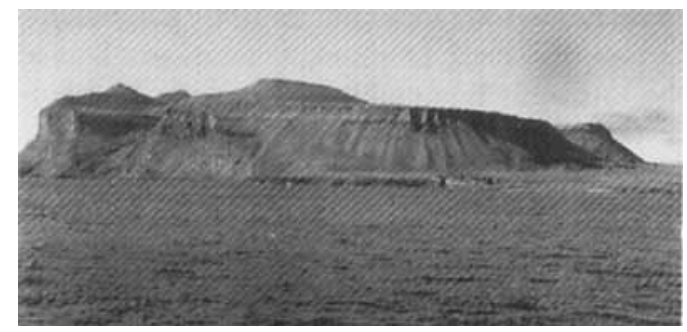

Fig. 2. Miseryfjellet viewed from the north-east. To the left the vertical cliff comprises Permian carbonates of the Miseryfjellet Formation. On the succecding plateau, softer Triassic shales form three peaks: from the left, Verdande. Urd and Skuld.

and the sedimentological evolution of the late Palaeozoic succession has been presented by Worsley et al. (in press). They show that tectonic stabilization took place in the Permian and that shallow marine platform environments developed over the entire island, probably extending onto large parts of the Barents Shelf. According to Krasilshchikov \& Livshits (1974), the entire late Permian (Kazanian and Tatarian) is missing, although biostratigraphical evidence for this hiatus has not been presented. The stable tectonic situation continued into the Triassic, although a large gap in sedimentation spans the PalaeozoicMesozoic boundary.

\section{Previous research on the Triassic of Bjørnøya}

The presence of Triassic rocks on Bjørnøya was first recognized on the basis of fossils collected during the Nathorst expedition of 1898 , and the succession was studied and sampled by Andersson (1900). Andersson's fossil collection was documented by Böhm $(1899,1903)$ who proposed a Carnian age for the uppermost $40 \mathrm{~m}$ of the succession; the age of the lower $140 \mathrm{~m}$ was not established. Andersson (1900) preferred an early Triassic age for these lower beds, though Nathorst (1910) advocated a Carnian age for the entire shale succession on the basis that it did not contain the very abundant bivalve fauna (daonellids or Posidonia) common on Spitsbergen.

British ecologists observed a labyrinthodont amphibian approximately $100 \mathrm{~m}$ below the top of the peak of Urd, and they covered the finds because they were unable to collect such a large fossil (Lowy 1949). (The three metres long amphibian was rediscovered in 1984 during a geological excursion by the Continental Shelf Institute (IKU). The remains were protected and excavated the following summer by technicians of the Palaeontological Museum in Oslo, and are now under preparation.)

In their stratigraphical synthesis of the Triassic succession of Svalbard Buchan et al. (1965) correlated the upper fossiliferous part $(64 \mathrm{~m})$ with the Kapp Toscana Group and the underlying $126 \mathrm{~m}$ with the Sassendalen Group on the basis of the observations of Andersson (1900) and Böhm (1903). They regarded the fossiliferous beds as Ladinian, based on the ammonoids reported by Böhm. For the entire Sassendalen Group on Bjørnøya they suggested a general Early and Middle Triassic age, although they indicated that the lower part of these shales could have been deposited in the Permian (Buchan et al. 1965, fig. 22). The biostratigraphy was further elaborated by Tozer \& Parker (1968), who made comparisons with the type sections in Canada (Tozer 1961, 1967). Tozer \& Parker postulated that '. . the presence of the Upper Ladinian Sutherlandi Zone in Svalbard is shown by the occurrence of Daxatina (= Dawsonites) canadensis (Whiteaves) on Bjørnøya (Böhm, 1903), in beds assigned to the Kapp Toscana Formation by Buchan et al. (1965, p. 47). Daxatina canadensis is restricted to the upper part of the Sutherlandi Zone in British Columbia and the specimens from Bjørnøya, described as having rounded saddles, seem to have been correctly identified by Böhm. Böhm's assignment of the beds to the Carnian is not justified. . . C Concerning the fauna derived from the overlying beds, Tozer \& Parker kept open the possibility that this could be of Carnian age.

The most thorough and interdisciplinary studies of the Triassic of Bjørnøya were carried out by Soviet expeditions in 1969 and 1970 (Pchelina 1972). By comparing the stratigraphical succession with that of the other islands in the Svalbard archipelago and with evidence from macrofossils (several of them poorly preserved), Pchelina postulated the presence of Lower $(50 \mathrm{~m})$, Middle $(0.2 \mathrm{~m})$ and Upper $(140 \mathrm{~m})$ Triassic sediments separated by depositional breaks in the upper part of the Lower Triassic and in the Middle Triassic. Pchelina (1972) correlated the lowermost beds $(22 \mathrm{~m})$ in Bjørnøya, on litho- 
logical criteria, with the lower part of the Sassendalen Group, and tentatively indicated an Induan (Griesbachian and Dienerian) age for these beds. The characteristic, although poorly preserved, ammonoid (Euflemingites) of the overlying beds is well known in the Smithian of Spitsbergen. ?Arctoceras blomstrandi was reported by Pchelina from a bed two metres below the phosphate conglomerate and she assigns this bed to the Smithian. It should be recognized, however, that Pchelina postulated a major break in sedimentation in the upper part of the Olenekian (Spathian). The two main units were interpreted as separated by a thin remanié conglomerate of phosphate cemented nodules containing variable amounts of other mineral grains. In fact the phosphatic conglomerate reflects multi-sedimentation processes, and Pchelina regarded the nodules as representing remains of the entire Middle Triassic, as similar phosphate nodules are reported in this part of the succession elsewhere in Svalbard. The uppermost part of the succession contains macrofossils dated as Carnian, and Pchelina correlated this with the Upper Triassic, on the basis of similarities with the other Svalbard islands, mainly Sørkapp Land, pointing to the dominance of detrital (?Permian) clastics in the lower part, and the change from dolomitic beds and concretions of the Lower Triassic succession to dominantly siderite concretions in the upper part. A transition in clay mineralogy was also reported, and the section contains on average approximately one percent organic carbon; the Lower Triassic succession has a higher $\mathrm{H} / \mathrm{C}$ ratio and a higher extractability than the upper part. This was attributed to the kerogen being mainly of marine origin in the lower part and mainly derived from higher plants in the upper part of the section.

The Soviet expeditions also resulted in a tectonic study, concentrating mainly on the preTriassic development of the island (Krasilshchikov \& Livshits 1974). According to these authors, the principal faults in the Permo-Triassic complex have a northeastern trend inherited from older fault systems. Based on the work of Pchelina, they assigned the lower part of the Triassic to the Urd 'Suite' and the upper part to the Skuld 'Suite'.

After a reconnaissance study in 1977 , formal lithostratigraphical units were defined for the Triassic succession by Mørk et al. (1982), who mainly adopted the stratigraphical concepts of Pchelina (1972). The lower $65 \mathrm{~m}$ were assigned to the Urd
Formation and included in the Sassendalen Group. The phosphate conglomerate was named the Verdande Bed and included in the Urd Formation. The whole upper part of the succession was named the Skuld Formation and correlated with the lower part of the Kapp Toscana Group.

The organic geochemistry of the Triassic rocks has been presented by Bjorøy et al. (1983) who reported a mixture of herbaceous and amorphous organic material in the Urd Formation, and mainly woody and herbaceous mixed with amorphous material in the Skuld Formation. The organic content varies between 0.6 and $2 \%$ and the deposits, especially the siltstones, contain a fair amount of extractable hydrocarbons. The source of the hydrocarbons in the Urd Formation is regarded as interbedded shales, while the siltstones of the Skuld Formation contain hydrocarbons both from interbedded shales and possibly from shales in the underlying Urd Formation. The chromatograms of the lowermost beds of the Urd Formation are, however, similar to those from Palaeozoic samples. The maturity of the succession corresponds to the lower part of the oil window (i.e. $0.9-1.1 \%$ Ro), and shows that a few kilometres of overlying rocks have been eroded. The Triassic succession on Bjørnøya has a fair to good potential to source hydrocarbons.

\section{The Triassic sediments}

The Triassic beds are preserved only upon the Permian mountain plateau that constitutes the basal part of Miseryfjellet (Figs. 1 and 2). Soft Triassic shales form three peaks: Urd, Skuld and Verdande. The most complete succession (type section for all units, Fig. 3) can be studied along the southern ridge of the highest peak (Urd), from the cairn at $346.6 \mathrm{~m}$ above sea level to the top of the mountain at $536 \mathrm{~m}$. The basal beds (Fig. 5) are also well exposed at the locality Osten between Urd and Verdande (Figs. 6 and 7). The Triassic beds rest disconformably, with a few degrees northerly dip, on the more resistant limestones of the Miseryfjellet Formation. Parts of the section are covered by shale debris from the overlying slopes.

\section{The Urd Formation}

The Urd Formation $(65 \mathrm{~m})$ consists of shales and siltstones with some sandstone beds at the base; 


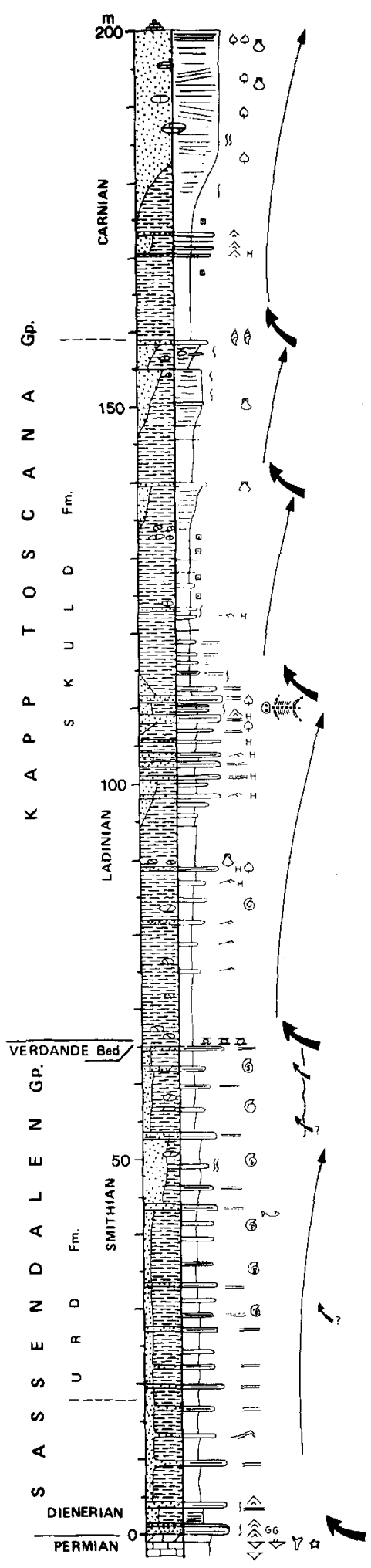

dolomite nodules and beds become increasingly common in the upper part of the formation.

The upper part of the underlying Miseryfjellet Formation was deposited in open marine environments, as demonstrated by a diverse fauna of brachiopods (both productids and spiriferids), bryozoans and echinoderms preserved in a marly limestone with abundant glauconite. A thin crust at the top of this unit consists of dolomite and ankerite veins that impregnate the fractured surface. It is only a few centimetres thick, and may have formed during either subaerial exposure or a submarine depositional hiatus between the deposition of the Miseryfjellet and Urd Formations. Krasilshchikov \& Livshits (1974) indicated that the upper parts of the Permian (Tatarian and Kazanian) are missing, but there is no reported fossil evidence to support this view. Palynological investigations (Konieczny 1987, written comm.) resulted in the recovery of poorly preserved material with long-ranging spores and pollen, which only allow a general Permian dating.

At the base of the Urd Formation type section (Figs. 3 and 5) a fine-grained brownish weathering laminated sandstone with wave ripples is overlain by a weakly consolidated and irregularly laminated bed $(0.3 \mathrm{~m}$ thick) which contains abundant glauconite. Then follow three thin partly laminated beds, the highest of which shows some bioturbation and wave ripples on its top. These lowermost beds contain abundant reworked debris, phosphate and glauconite grains, as well as abundant iron-oxides between the grains. The abraded nature of the grains suggests that they were derived from the underlying Permian unit.

At Osten (Figs. 5, 6 and 7), $1.3 \mathrm{~km}$ north of the type section, a more shaley development is seen, although glauconite-rich planar bedded sandstones are also present, resting conformably on a well developed dolomitic crust in the Miseryfjellet Formation.

The lower $25 \mathrm{~m}$ of the Urd Formation contain no macrofossils and sparse bioturbation is only observed in the lowermost beds, which are partly covered by scree. The main part of the succession consists of grey laminated silty shale, with thin $(10-20 \mathrm{~cm})$, yellow weathering, dolomitic siltstone beds. The lowest and thickest $(50 \mathrm{~cm})$ bed is planar laminated, and has linguoid wave ripples

Fig. 3. Interpretative sedimentological section of the Triassic succession of Bjørnøya, measured along the southern slope of Urd. Legend in Fig. 4. Thick arrows indicate transgressive development, thin arrows regressive development. 


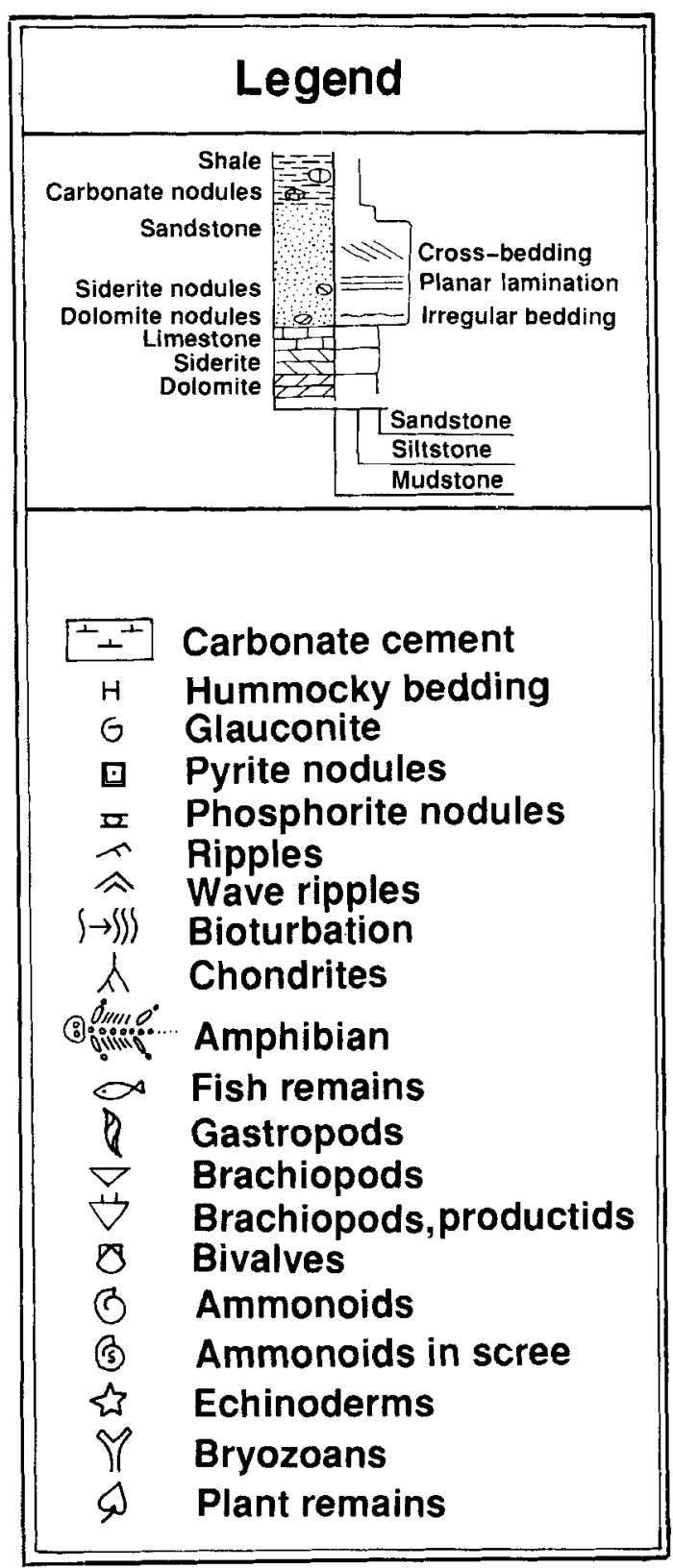

Fig. 4. Legend to sections.

Fig. 5. Sections of 'the basal Triassic beds: southernmost part of Urd and Osten. Legend in Fig. 4.

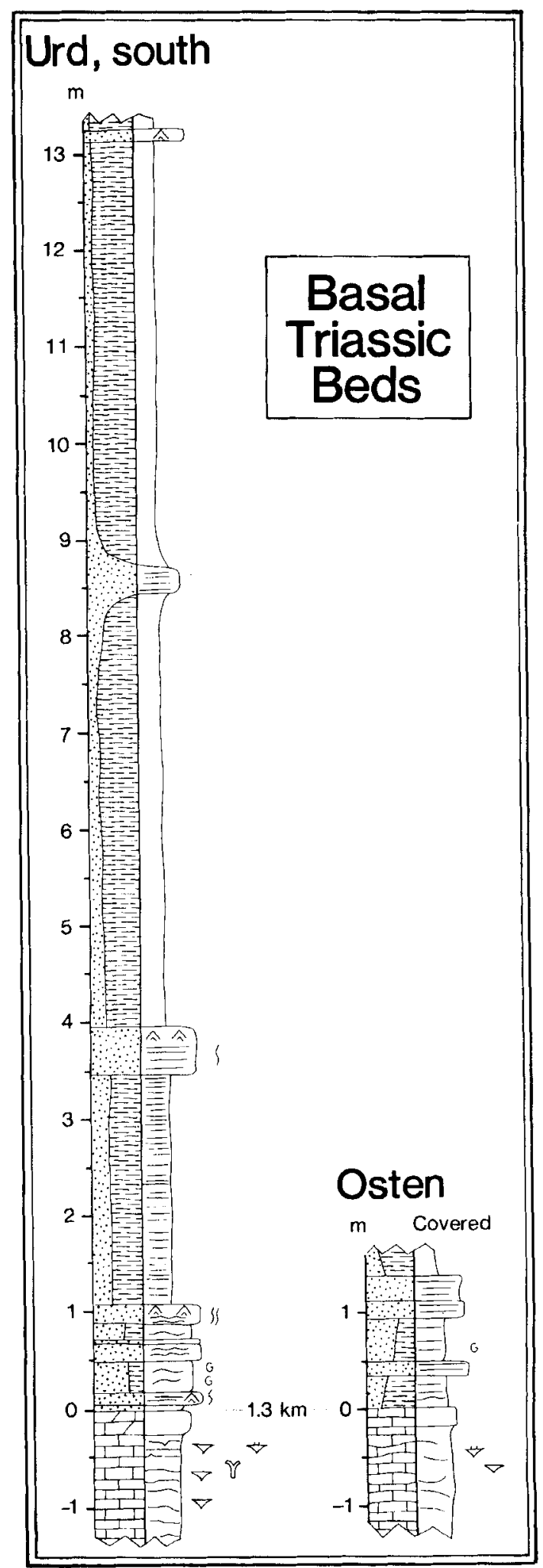




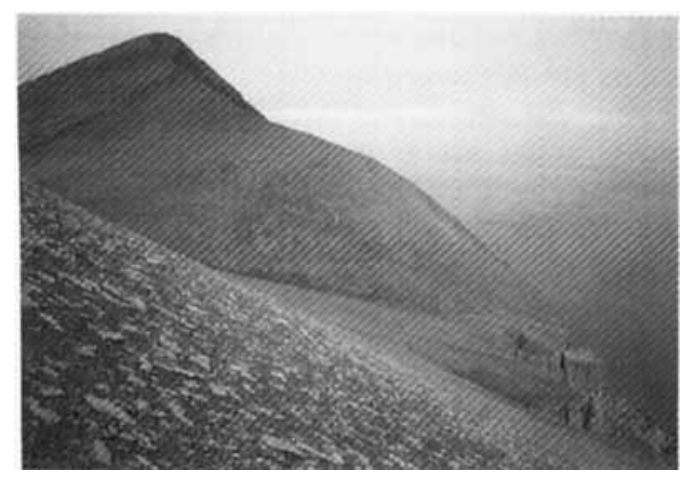

Fig. 6. The Urd and lower part of the Skuld Formations on the southern slope of Verdande. The Permian limestone and basal Triassic beds are exposed at the locality Osten in the right part of the photo.

in its upper part. The overlying siltstone beds are laminated, one showing linguoid wave ripples. Ripple drift lamination was observed in one bed $12 \mathrm{~m}$ above the base. The remainder of the succession contains parallel laminated beds without traces of bioturbation. The organic material reflects mixed marine and terrigenous sources.

In the middle and upper part of the Urd Formation, from approximately $25 \mathrm{~m}$ above base, the sediment shows darker colours than below. In the lower part of this interval poorly preserved ammonoids occur as imprints in dolomite cemented nodules and siltstone beds. These are referred to the genus Eufleminigites by Pchelina (1972) and by Wolfgang Weitschat (pers. comm. on our material); this genus is very common in the lowermost beds of Smithian age elsewhere in Svalbard. Fish remains are also observed in the central part of the sequence; such remains are

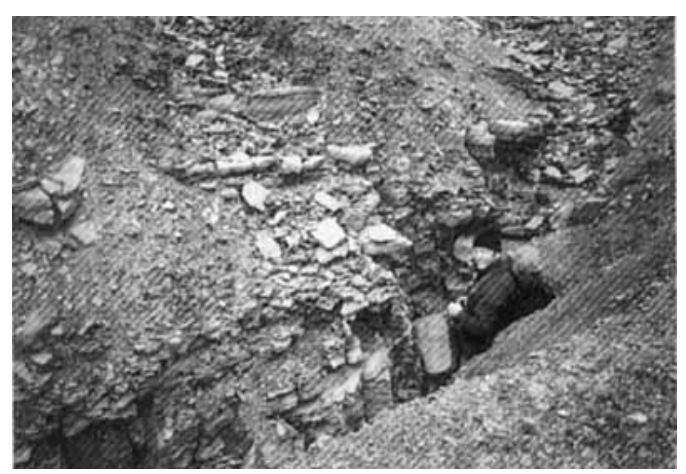

Fig. 7. The basal sandstone beds of the Urd Formation which overlie the limestones of Miseryfjellet Formation at the locality Osten. abundant in the Sticky Keep Member in Spitsbergen.

The number of siltstone beds increases towards the top of the formation, giving the section the appearance of a minor coarsening upward unit, although the coarsening is not as pronounced as often seen on Spitsbergen. The siltstone beds, dominated by quartz and with only subordinate mica, contain abundant dolomite cement in the lower part of the unit. Towards the top of the Urd Formation, the silt content decreases and the siltstones are replaced by dolomite beds. Faint lamination is normally seen in these beds, and bioturbation is sparse and restricted to very few beds.

The silty dolomitic beds close to the top of the formation contain a few poorly preserved ammonoids and bivalves. These beds have been treated in detail by Pchelina (1972), who regarded them as a condensed sequence, including periods of low or non-deposition. Pchelina also reported the presence of the ammonoid? Arctoceras blomstrandi. A fish jaw fragment from this level is assigned to Saurichthys (Franz-Josef Lindemann, pers. comm. 1989), a genus mainly known from the 'Fish Horizons' of Smithian age on Spitsbergen (cf. Stensiö 1925). The dolomites are argillaceous, partly laminated and recrystallized There are common imprints of bivalves, which often occur as small cavities filled by drusy carbonate minerals, mostly dolomite but also quartz. The dolomite beds are overlain by a few metres of carbonaceous, argillaceous and silty rocks with dolomite concretions. Pchelina (1972) also reported abundant algal filaments and a high content of organic matter in these beds.

The Verdande Bed is a thin conglomerate of grey phosphatic nodules (Fig. 8), which rests on the upper dolomite bed of the Urd Formation. The dark grey nodules range up to $10 \mathrm{~cm}$ in diameter, and include globular and irregular forms; many are flattened. The nodule bed is also accessible on the southern slope of Verdande, where a more diverse assemblage of nodules can be sampled than at the type locality which has been visited by more geologists during the last decade. The nodules have a heterogeneous composition of embedded clastic grains and phosphate intraclasts, but no body fossils have been found.

Thin sections from the phosphate cemented nodules (Fig. 8) display high but variable concentrations of clastic grains. Some nodules contain heterogeneous grain assemblages including 

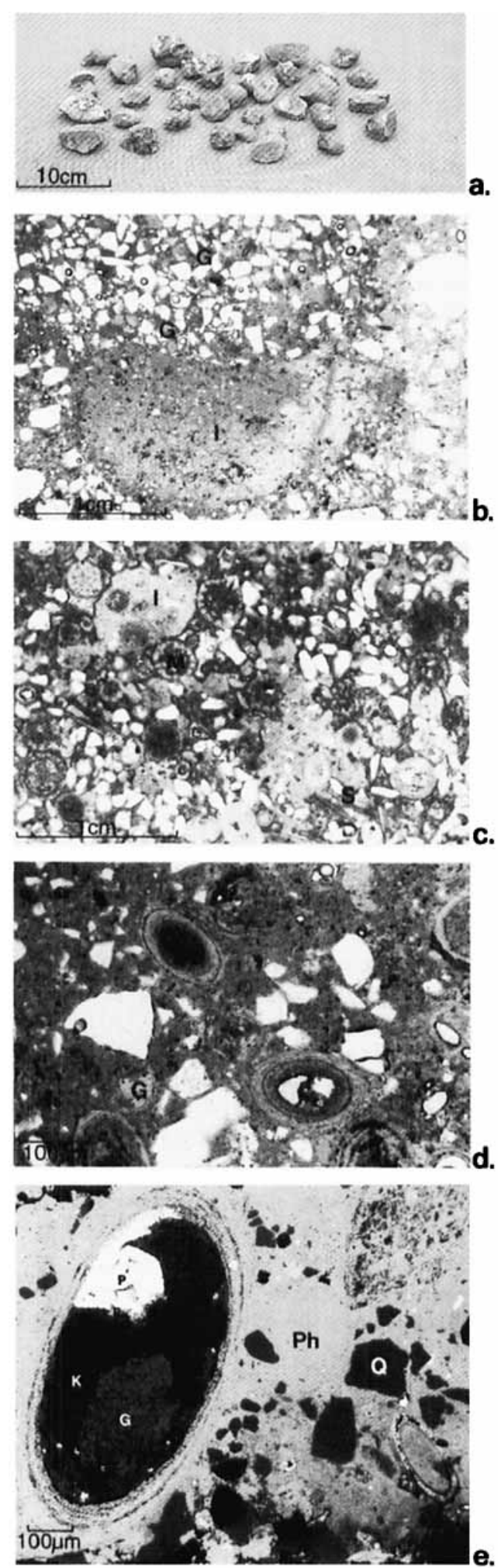

mica flakes and abraded glauconite grains, while others are dominated by quartz. The degree of sorting also varies, and in one thin section the quartz grains are better rounded than in the others. The clastic grains indicate a heterogeneous source. Most of the nodules contain grain supported textures and the phosphate occurs as a microcrystalline cement between the clastic grains, although in small areas the clastic grains are floating in the phosphate matrix. Fossil fragments in the nodules include sponge spicules, bivalve fragments, ostracode shells and the algae resembling Mizzia. Sponge spicules and the Mizzia-like algae are most abundant and are generally phosphatized, although small parts of the fossil walls may consist of chert. Ooids occur in two thin sections and are mostly phosphatized; some have central cavities filled with minerals such as glauconite, quartz, pyrite and more seldom kaolinite and clay matrix. Cavities in intraclasts are either empty or filled with secondary minerais such as glauconite, kaolinite and pyrite. Three thin sections have been studied by electron microscope and analysed by microprobe. The mineral composition of the amorphous phosphate varies very little between the nodules and between the phosphatic intraclasts and the matrix. Calculation of the mineral formula shows that there is scarcely any carbonate present in the apatite structure, while fluorine is abundant. This composition contrasts with results from Middle Triassic phosphate nodules from Spitsbergen, which consist of francolite (carbonate apatite).

\section{The Skuld Formation}

The upper $135 \mathrm{~m}$ of the section on Urd mountain are assigned to the Skuld Formation, which consists of several minor coarsening upwards sequences, grading from grey to dark grey shales with red weathering siderite nodules, to finegrained sandstone (Fig. 3). A grey shale directly

Fig. 8. Nodules (a) and thin section photos (b-c) from the Verdande Bed. $b$. Thin section of phosphate nodules. Phosphatized intraclast (I) is embedded in a grain-supported phosphate cemented sandstone. Light coloured grains are quartz, grey grains are glauconite (G). c. Phosphate cemented sandstone with phosphate intraclasts (I), ?sponge spicules (S) and the alga Mizzia (M). d. Phosphatized oolites embedded in a phosphate matrix. Grey coloured grains are glauconite $(G)$. e. SEM backscatter electron photo of an ooid in phosphatic matrix $(\mathrm{Ph})$, note that ooid walls are also phosphatized. The cavity of the ooid contains glauconite $(G)$, kaolinite $(K)$ and pyrite $(P)$ : quartz grains in the matrix arc grey $(Q)$. 


\section{Skuld Formation Lower sandstone cycle}

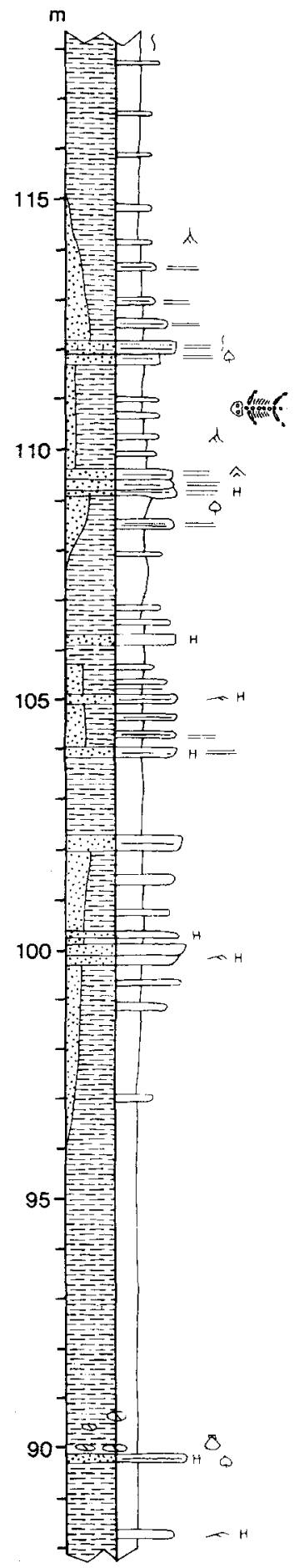

overlies the Verdande Bed, and contains abundant small siderite nodules. The siderite is finegrained (micritic), and only contains minor quartz grains. The nodules vary from only a few centimetres to tens of centimetres in diameter. The latter flattened discs often form nodular beds, which vary in abundance upward throughout the formation. There are no silt or sandstone beds in the lower few metres of this shale, but such beds occur from approximately $10 \mathrm{~m}$ above the base of the formation and the abundance of thin siltstone beds increases upwards through the lower sequence, although very fine sand grade is rarely reached. Current activity is indicated by asymmetric ripples in the lower beds, while hummocky cross lamination and wave ripples interbedded with parallel lamination occur in the upper part of the succession. Plant debris are abundant, especially as minute fragments on top surfaces of siltstone beds.

Approximately $100 \mathrm{~m}$ above the base of the section, a sandy interval (Fig. 9) contains abundant thin sandstone beds with planar lamination, hummocky bedding and wave ripples. The beds become coarser, thicker and more abundant upwards, and culminate in two sandy beds a few metres thick, separated by a few metres of shale. Linguoid wave ripples and plant fragments are abundant in these sandstones. The sandstone interval grades upwards into grey shale with silt and sand lenticles. A three metre long labyrinthodont amphibian (Fig. 10) was found between these sandstone beds. The amphibian remains consist of fragmented phosphatic bones preserved in a shaley interval between silt/sandstone beds. Combinations of wave ripples and hummocky bedding indicate shallow depositional environments. Marine fossils occur both below and above the sandy part of this interval. Most probably the amphibian lived at least partly on land, and this part of the sequence may have been deposited close to the shoreline.

Several minor coarsening upwards sequences (mainly from shale to siltstone) occur between 120 and $175 \mathrm{~m}$. These sequences vary from only a few metres to nearly $10 \mathrm{~m}$ in thickness. Occasional bivalves are present, mostly daonellids or Halobia. Sparse rippling and hummocky bedding are also observed, although the bedding in the

Fig. 9. Sedimentological section from the lower sandy cycle of the Skuld Formation. Note localization of amphibian between the thin sandstone beds. Legend in Fig. 4. 


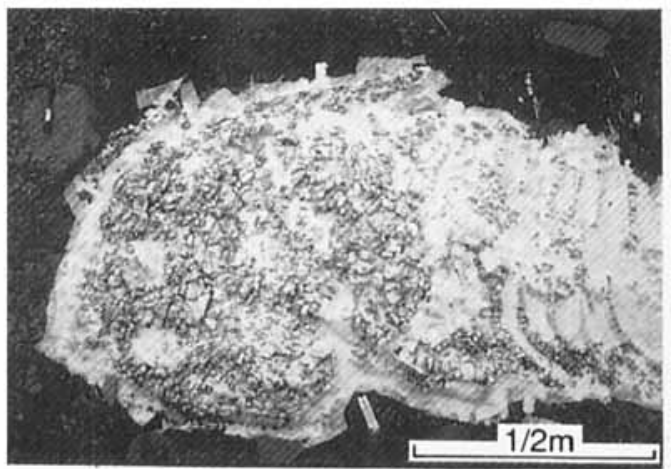

Fig. 10. The head and some ribs of the amphibian. The fragmented fossil was protected by silicon during excavation. Photo Bjorn Tore Simonsen.

siltstones and sandstones is mostly irregular. The upper sandstone unit contains both wave ripples and hummocky cross bedding. Some beds have sparse bioturbation in their upper part. At $168 \mathrm{~m}$, a bedding surface has abundant gastropods, mostly preserved as siderite steinkerns.

The top sandstone (Fig. 11) comprises very fine- to fine-grained thinly to thickly bedded $(0.1$ to $1 \mathrm{~m}$ ) sandstone, and is slightly more than $20 \mathrm{~m}$ thick. Below this sandstone, some thin siltstone beds show wave ripples. Parts of the sandstone contain low angle cross-beds; some beds continue across the entire exposure in the cliff below the mountain top. Several large and some minor carbonate nodules are present. Bioturbation is observed locally. Plant debris are abundant, and imprints of bivalves are common, especially towards the top. The fauna also includes ammonoids (Böhm 1903).

Thin sections (Fig. 12) generally show a heterogeneous mineralogy, and diagenetic fabrics

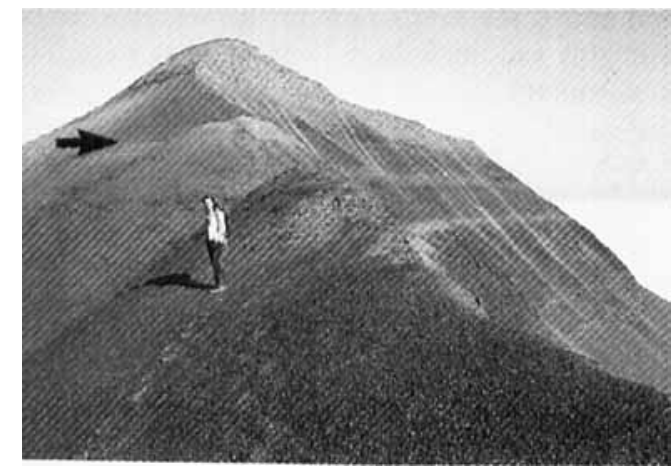

Fig. 11. The upper sandstone of the Skuld Formation, Urd mountain. The Carnian cycle is interpreted as starting at the level of the arrow.
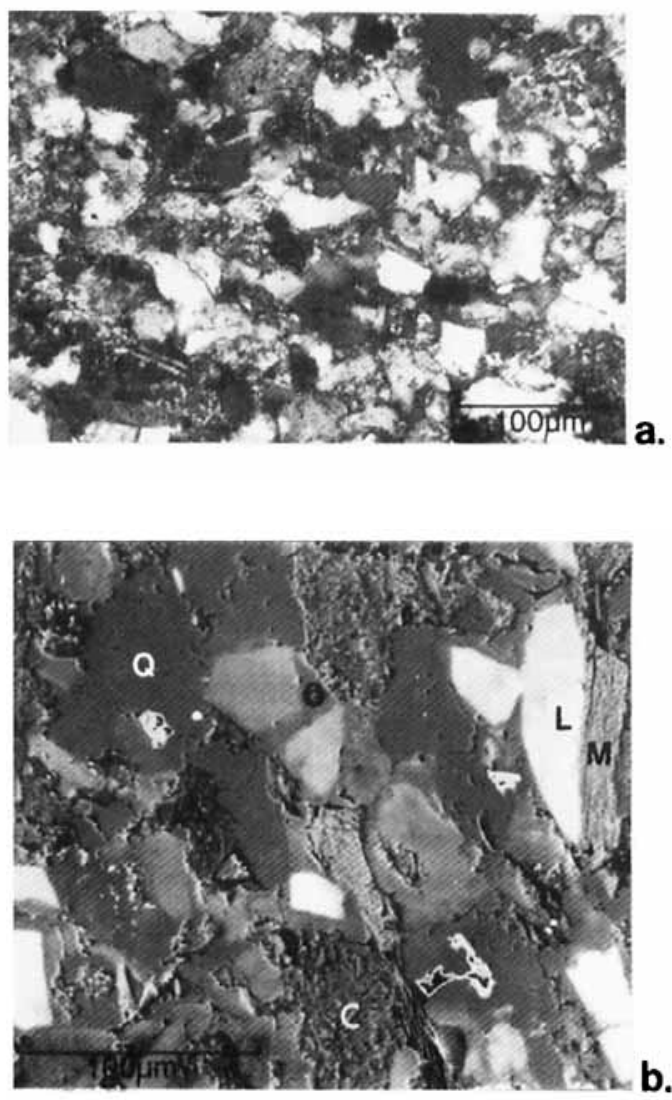

Fig. 12. a. Thin section photo in crossed polarized light showing the heterogeneous nature of sandstones from the Skuld Formation $(189.00 \mathrm{~m})$, b. Combined SEM backscatter and cathodoluminescence image of a sandstone from the Skuld Formation $(106.10 \mathrm{~m})$. The smooth grey areas are quartz grains $(\mathrm{Q})$ and overgrowth $(\mathrm{O})$, the lighter areas are luminescing primary quartz grains (L). Lighter grey grains are mica flakes (M) and the rough grey matrix is composed of clay minerals (C). The bright rim cement is siderite.

are more extensive in the upper sandstone unit than in the sandstone in the middle part of the formation. Mica and plagioclase are abundant in the upper sandstone, and plastic squeezing, mainly of clay minerals, has blocked most of the pores, while later quartz overgrowth has sealed off any remaining porosity. Cementing minerals in the sandstone include quartz, illite and chlorite, in decreasing amounts. There is no preserved primary porosity or observed secondary porosity. This mineralogy clearly contrasts with the clean quartz sandstones of the Urd Formation. 


\section{Mineralogy by $X R D$}

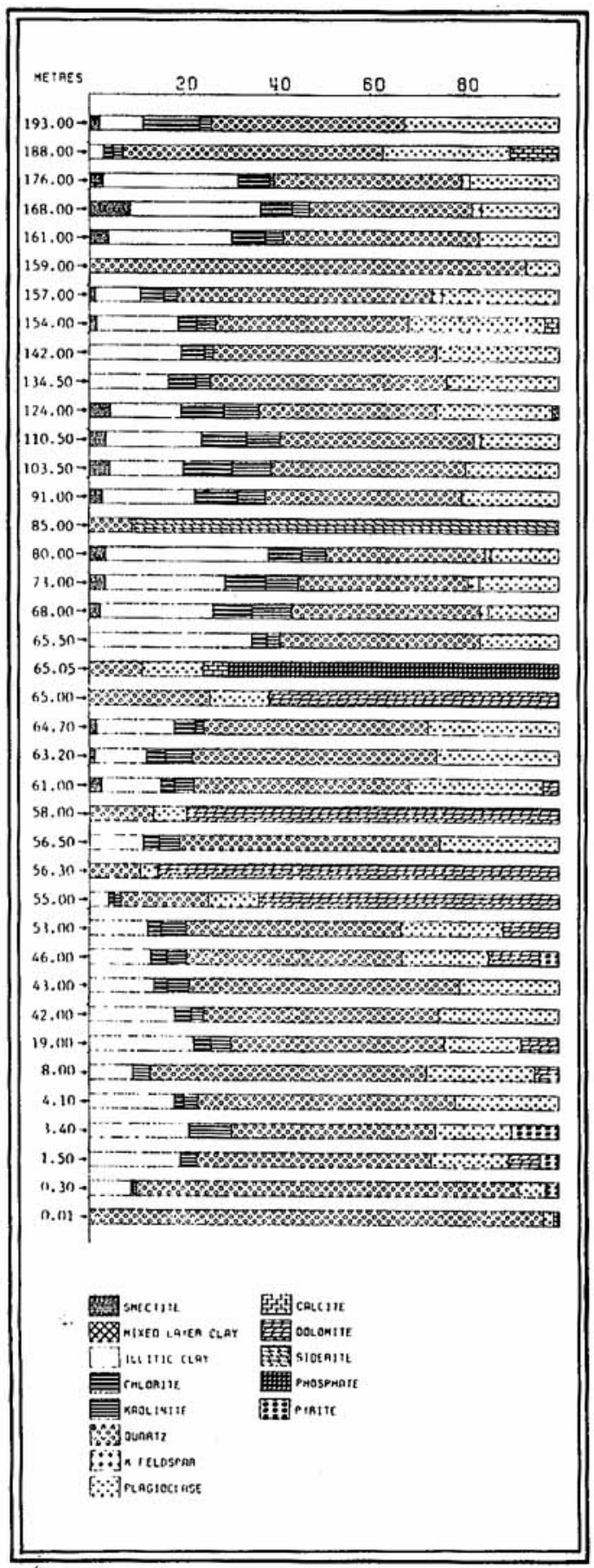

Fig. 13. Plots of XRD-results.
Thirty-nine samples of shales, silty shales, carbonate and phosphate nodules have been analysed by X-ray diffraction (Fig. 13). Trends throughout the succession reflect both primary mineralogy and diagenesis.

\begin{abstract}
Analytical procedure: The samples were gently crushed and sucked onto millipore filters for whole rock analysis. The minerals were identified as indicated below, and the quantification was based on peak height multiplied by the width of the peak at half maximum height. The results were multiplied by a weighted factor relative to quartz. The $7 \AA$ minerals were split into kaolinite and chlorite by calculating the relative percentage of the height of the $3.58 \AA$ and $3.54 \AA$ peaks, respectivcly. Phosphate was detected by three characteristic peaks $(2.80 \AA, 2.68 \AA$ and $2.62 \AA)$; the major peak at $2.80 \AA$ was used for calculations. The $d$-values and the weighted factor for the different minerals are: Smectitc: approximatcly $14 \AA, 0.35$. Mixed layer minerals: $10-14 \AA, 0.55$. Illite: $10 \AA \AA, 1.4$. Kaolinite and Chlorite: $7 \AA, 0.7$. Quartz: $4.26 \AA$, 1.0. K-feldspar: $3.24 \AA$, 0.5. Plagioclase: $3.19 \AA, 0.5$. Calcite: $3.03 \AA, 0.25$. Dolomite: $2.89 \AA, 0.2$. Siderite: $2.79 \AA, 0.25$. Apatite: $2.80 \AA \hat{A}, 0.3$. Pyrite: $2.71 \AA, 0.7$.
\end{abstract}

The shales of the Skuld Formation have a higher clay mineral content than the Urd Formation, and there is an abrupt increase at the formation boundary. The increase is due to higher proportions of both illite and $7 \AA$ minerals. Kaolinite is dominant over chlorite in the Urd Formation, while the reverse is seen in the Skuld Formation. Smectite is detected in the Skuld Formation as well as in the uppermost metres of the Urd Formation. The concentrations of quartz and feldspars simply reflect the silt and sand content of the shales. Alkalifeldspars are only found in minor amounts in the Skuld Formation, while plagioclase is common throughout the section, but most abundant in the upper unit.

Diagenetic minerals occur as cement in clastic beds and in nodules. Dolomite is only recorded in the Urd Formation. The nodules of the Verdande Bed have phosphate cement without any calcite, while in the remaining part of the Skuld Formation nodules consist of siderite, and calcite is only present as a minor constituent (cement) in some siltstone beds. Dispersed pyrite is common as a minor constituent in the Urd Formation and it is present in the shales of the Skuld Formation as discrete nodules.

\section{Palynology}

The palynological investigations involved the study of about 140 samples from the Urd Forma- 


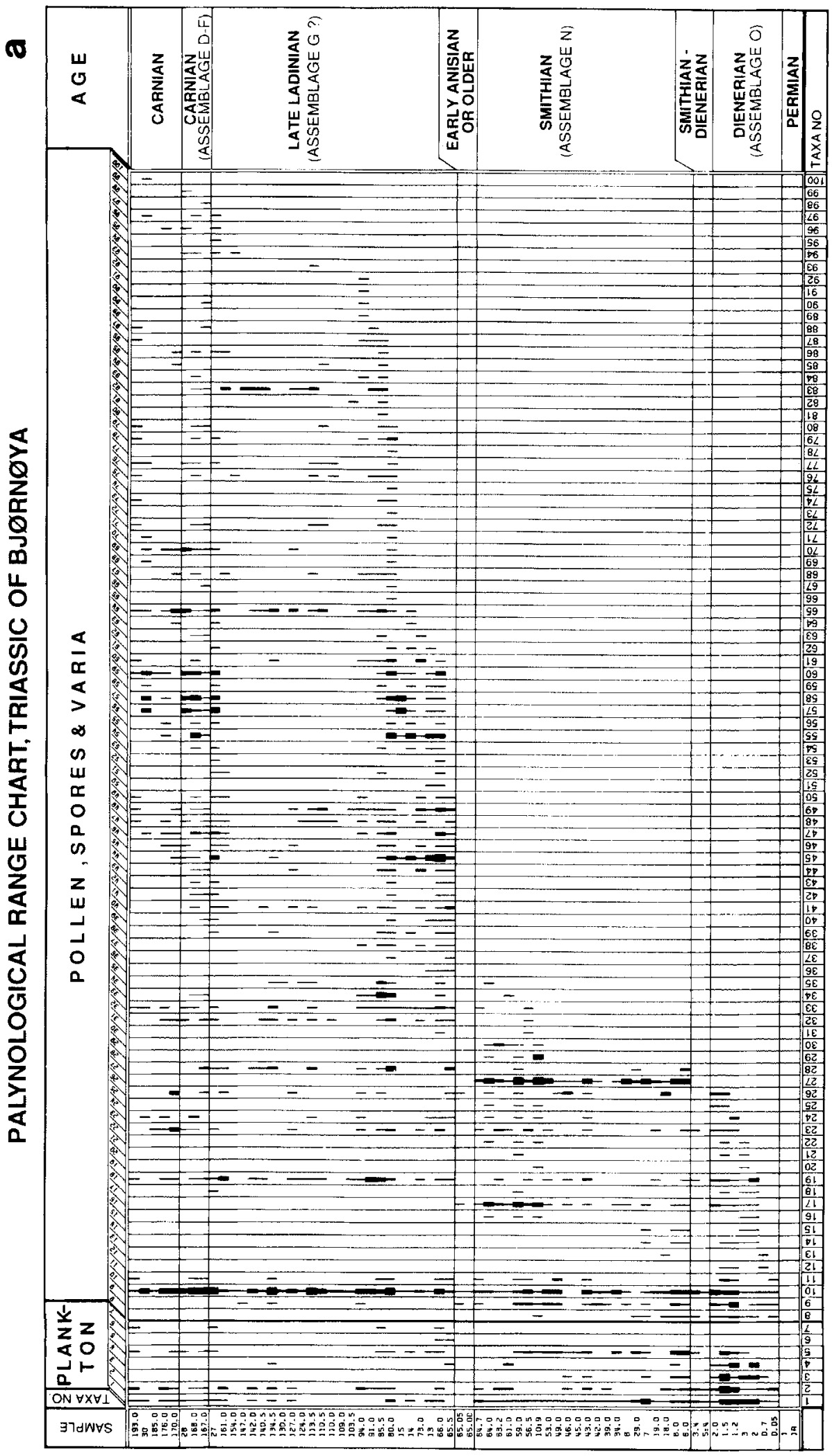

产

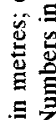

葛

茨

参

8.

จั

은

起

焉

ปั

논

㫣

을

募

들 농

号的

范

武

万人

虽总是

乙

巳

통

范要

它总

总要

范每

过

苛

氖

果告

을 至

苞苞

量点

言文

施

步苋

事是 


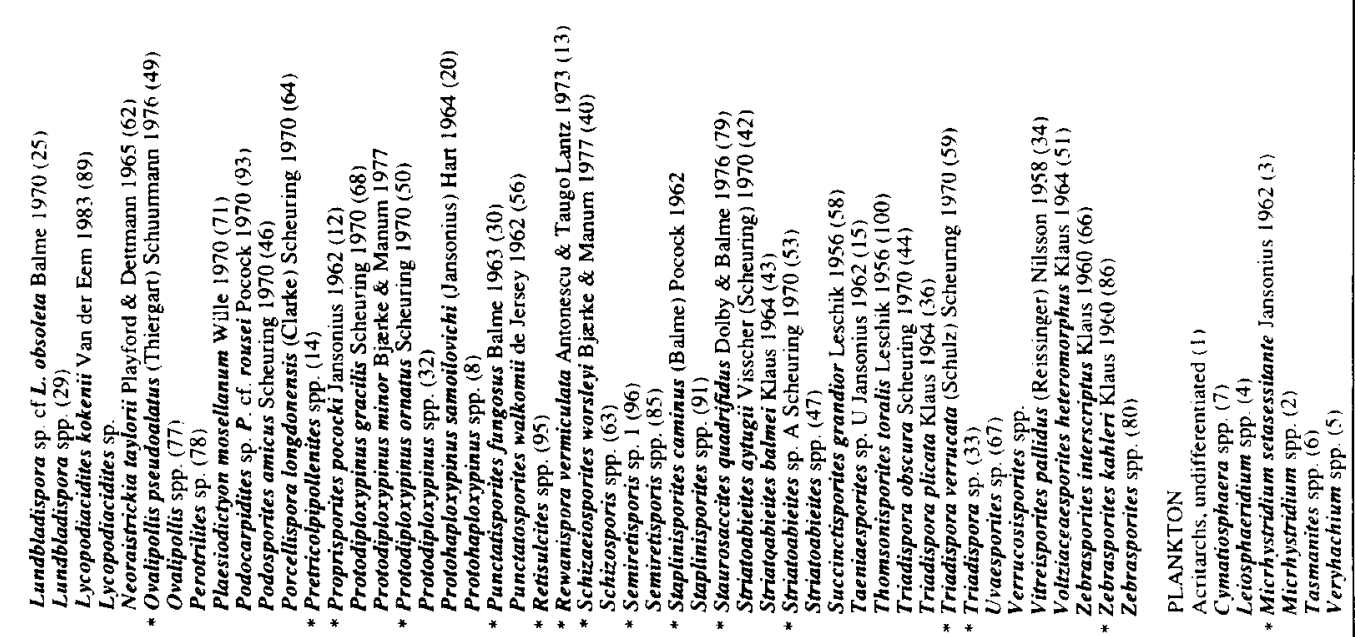

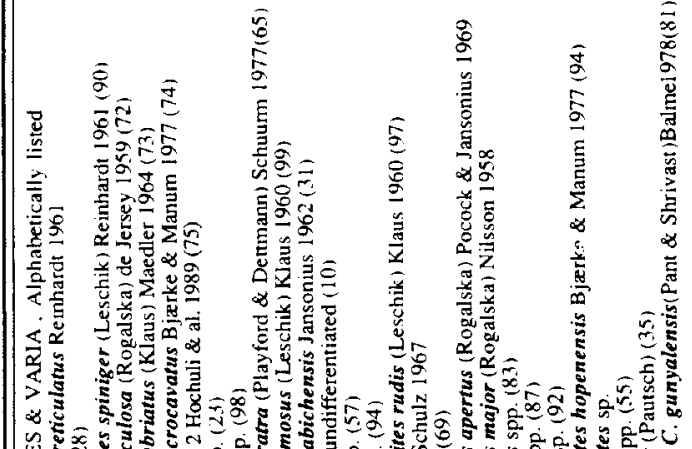

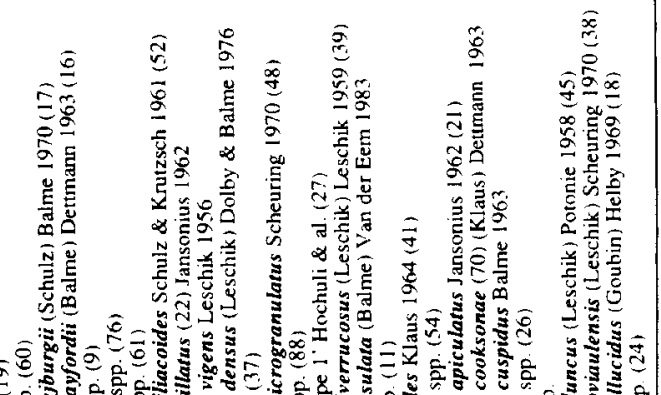

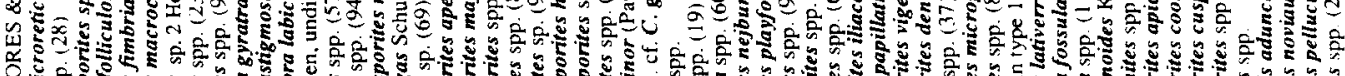

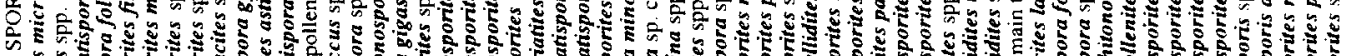
z

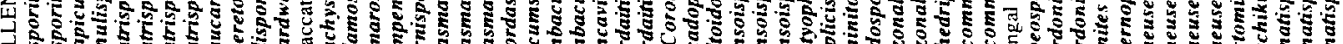

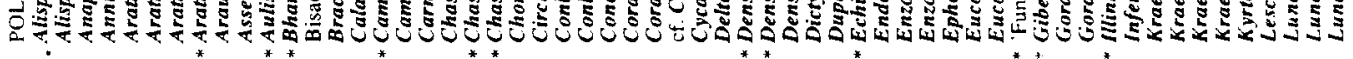
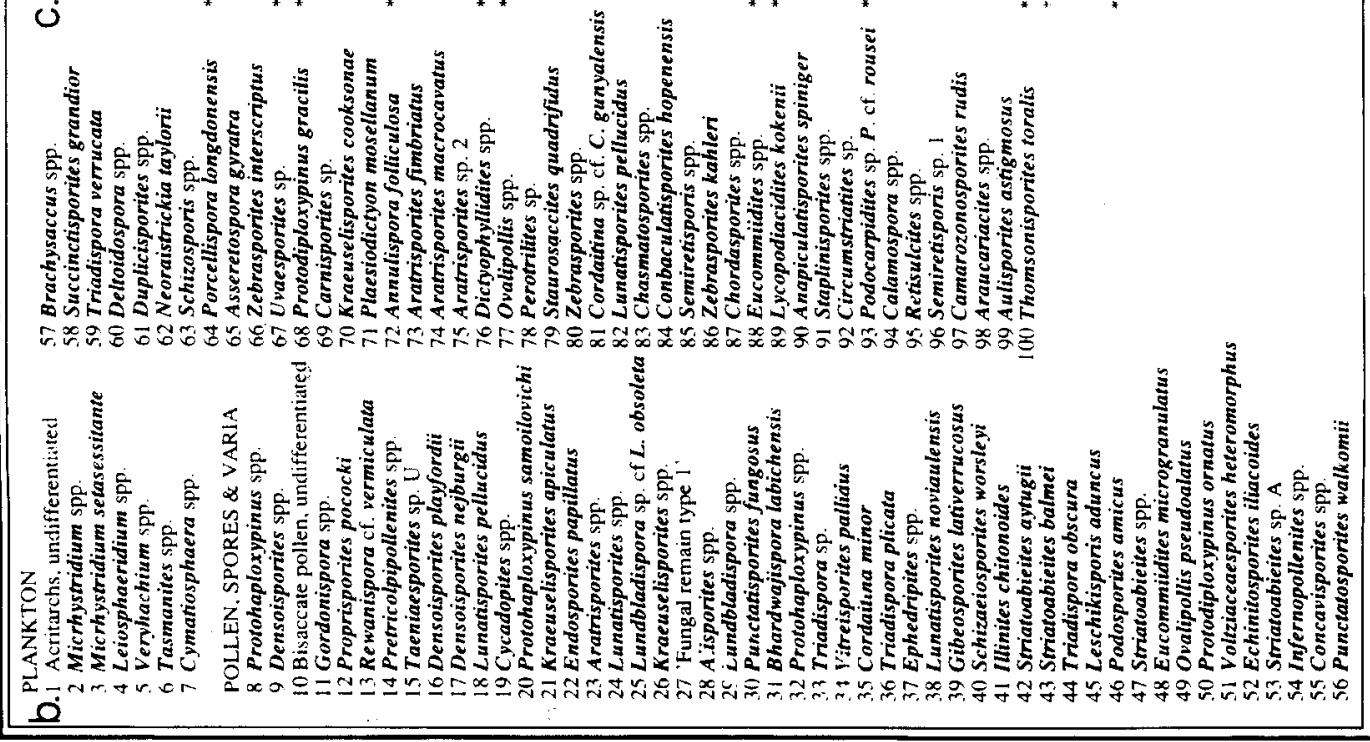
tion, the Verdande Bed included, and the Skuld Formation.

About half of the samples were barren, and are not included in the distribution chart (Fig. 14a). Most of the palynomorphs recovered are poorly preserved (Figs. 15 and 16), resulting in difficulties in identification. Some samples yielded reasonably well preserved and diverse microfloras; variations in the diversity of the microfloras are attributed largely to differences in the state of preservation. There are, however, clear differences between assemblages dominated by spores and acritarchs in the Urd Formation (Fig. $14 \mathrm{a}$ ) and the spore or pollen dominated assemblages of the Skuld Formation (Figs. 14a and 15). An alphabetic list of the taxa recorded is presented in Figs. 14b and c.

The recent study by Hochuli et al. (1989) reviews the relevant palynological studies for the Barents Sea area, and establishes a palynostratigraphic framework for the Triassic of this area. The study was based on material from onshore Svalbard and from scientific and exploration drilling in the Barents Sea. In the present study the palynomorph assemblages from Bjørnøya are compared with assemblages 'A-P' of Hochuli et al.

Two palynomorph assemblages are recorded from the Urd Formation (Fig. 14a):

$-0.05-2.0 \mathrm{~m}$, the Dienerian 'Assemblage $O$ '.

Between 2.0 and $6.0 \mathrm{~m}$, a non-diagnostic Early Triassic assemblage.

-6.0-64.7 m, the Smithian 'Assemblage N'.

The nodules from the Verdande Bed yielded only a few palynomorphs. The record of Densoisporites nejburgii in one sample $(65.05 \mathrm{~m})$ is taken as evidence for an age older than Middle Anisian. However, the possibility of reworking has to be considered.

In the Skuld Formation we recognize the following palynological assemblages (Fig. 14a):

-65.5-c. $164.0 \mathrm{~m}$, a Late Ladinian assemblage (probably 'Assemblage G').

-Sample 28 at around $169 \mathrm{~m}$ and the sample at $167.0 \mathrm{~m}$ contain a diverse microflora comparable to the early to 'middle' Carnian 'Assemblage F-D' of Hochuli et al. (1989).

-170.0.-193.0 $\mathrm{m}$, an undifferentiated Carnian microflora.

The assemblages suggest that much of Anisian and Ladinian time may be unrepresented and that a substantial hiatus occurs between the two formations. The Ladinian-Carnian boundary is considered to be located around $165.0 \mathrm{~m}$ but is not clearly defined palynologically.

\section{The palynomorph assemblages of the Urd Formation}

The palynomorphs from the lowest part of the Urd Formation $(0.05-2.0 \mathrm{~m})$ are poorly preserved. Indeterminate bisaccate pollen, cavate spores (Densoisporites nejburgii, Kraeuselisporites sp.), acritarchs (Micrhystridium setasessitante, Micrhystridium spp., Veryhachium sp.) and leiospheres are dominant. Proprisporites pococki and Rewanispora cf. vermiculata occur at $0.7 \mathrm{~m}$; Cycadopites sp. is quite common, in contrast to the succeeding interval. Pretricolpipollenites sp. occurs sporadically and Aratrisporites spp. occurs regularly together with bisaccates.

A corresponding assemblage characterized by abundant Cycadopites sp., Pretricolpipollenites and numerous acritarchs and leiospheres comprises 'Assemblage O' of Hochuli et al. (1989), which has been recovered from the Vardebukta Formation in Spitsbergen, above the oldest Triassic palynological 'Assemblage $\mathrm{P}$ ' in Festningen. Farther north in the Bertilryggen section this assemblage occurs in association with a Dienerian fauna. In the present investigation Proprisporites pococki has also been found in an 'Assemblage $O$ ' association in Bjørnøya. Unpublished results (Vigran) from cored material from the Barents Sea show that the taxon ranges into the Late Smithian Wasatchites tardus ammonoid zone, and thus extends higher than recorded by Hochuli et al. (1989).

Similar assemblages, with common Cycadopites and including Proprisporites pococki, were described from the Early Triassic of western Canada by Jansonius (1962) and from Greenland (Griesbachian) by Balme (1980). Utting (1985, 1989) records $P$. pococki and Gnetaceaepollenites steevesi in the oldest Triassic 'Tympanicysta stoschiana - Striatoabieites richteri' assemblage zone of Melville Island in the Sverdrup Basin.

Jarosenko \& Golubeva (1981) reported two 'aspects' of a late Early Triassic 'Complex II' from the Timan Pechora region, and considered them to represent stratigraphically different levels, facies variations or phytogeographic provinciality. One assemblage, which resembles the oldest assemblage (?Dienerian) in Bjørnøya, is dominated by Densoisporites spp. and Cycadopites spp., and may have abundant acritarchs. 
Apart from the occurrence, often in abundance, of 'Fungal remains type 1' at $6.0 \mathrm{~m}$, the composition of the assemblages remains quite homogeneous up to the uppermost part of the Urd Formation. They are characterized by abundant spores, including Punctatisporites fungosus. Rewanisporites cf. vermiculata occurs occasionally. Variations in diversity are regarded as due to the different states of preservation.

The samples, particularly up to $42.0 \mathrm{~m}$, contain poorly preserved palynomorphs. The better preserved material between 43.0 and $64.0 \mathrm{~m}$ has a higher proportion of large spores, indicating an increased terrestrial influx. Cavate spores are common, especially Densoisporites spp., $D$. nejburgii and Kraeuselisporites spp., as well as Aratrisporites spp. Hochuli et al. (1989) term this association 'Assemblage $\mathrm{N}$ ' and also report it from the Tvillingodden Formation in Spitsbergen. The late Early Triassic 'Complex II' of Jarosenko \& Golubeva (1981) is dominated by Verrucosisporites spp., Punctatisporites spp. and Aratrisporites spp., and is reminiscent of the assemblage in the upper part of Urd Formation, supporting the view of Jarosenko \& Golubeva that the regionally different aspects of their 'Complex II' represent different stratigraphical levels.

The samples show very poor productiveness in the uppermost part of the Urd Formation (64.0$65.0 \mathrm{~m})$, and have a higher proportion of densely aggregated degraded material. The aggregates have a granular structure which may possibly be related to the activity of blue green algae. Algal structures have also been reported by Pchelina (1972) from this level.

The distinct change in the distribution pattern of palynomorphs above the level of the Verdande Bed (Fig. 14a) gives clear evidence for the important break in deposition. The presence of Densoisporites nejburgii is one feature the Verdande Bed has in common with the underlying part of the Urd Formation. However, this species ranges up into the Early Anisian, where it occurs rather sporadically. It is also possible that it represents reworking from the Lower Triassic sediments.

\section{The palynomorph assemblages of the Skuld Formation}

The lowest sample from the Skuld Formation, at $65.5 \mathrm{~m}$, contains a poor palynomorph assemblage comprising mostly long ranging pollen and spores and a few acritarchs. A special feature is Schiz- aeoisporites worsleyi and the frequent occurrences of Illinites chitonoides, Ovalipollis pseudoalatus and Leschikisporis aduncus.

A relatively rich and diverse assemblage is recorded from $66.0 \mathrm{~m}, 1 \mathrm{~m}$ above the Verdande Bed (Figs. 14a and 15). It is characterized by abundant spores, mainly Leschikisporis aduncus and Concavisporites spp., as well as bisaccate pollen. The lowest records of Echinitosporites iliacoides, Triadispora verrucata, Podosporites amicus, common Chasmatosporites spp. and Ovalipollis pseudoalatus are in this association, which is comparable with a Late Ladinian assemblage in the Barents Sea area (Hochuli et al. 1989).

Well preserved palynomorphs have been recorded at 80.0 and $85.5 \mathrm{~m}$ where the stratigraphic incoming of species such as Annulispora folliculosa, Kraeuselisporites cooksonii, Plaesiodictyon mosellanum, Stauroasaccites quadrifidus and Zebrasporites interscriptus is indicative of an age no older than Late Ladinian. These species have previously been reported from the Late Triassic of Spitsbergen, Hopen and Kong Karls Land (Bjærke \& Dypvik 1977; Bjærke \& Manum 1977; Smith et al. 1975). They are also present (Vigran unpublished data) at the base of the Tschermakfjellet Formation (Carnian) and in the uppermost part of the Sassendalen Group (Ladinian) in Spitsbergen.

Hochuli et al. (1989) differentiate two assemblages $(\mathrm{G}$ and $\mathrm{H})$ in the upper part of the Ladinian of the Barents Sea area on the basis of the extinction of a distinctive acritarch 'Cymatiosphaera sp. 1'. Echinitosporites iliacoides occurs in both assemblages and ranges to the top of the Ladinian, whereas 'Cymatiosphaera sp. 1' seems to be absent from the higher assemblage (G). In the present material Cymatiosphaera sp. 1 has not been found. This may be due to the generally poor preservation of the palynomorphs and deterioration of this rather fragile acritarch, or it could mean that only 'Assemblage $G$ ' is present in the uppermost Ladinian part of the Skuld Formation. On the other hand, the two assemblages may represent different marine environments, the more shallow conditions having developed in Bjørnøya only.

Palynodebris in the interval from 65.5 up to $94.0 \mathrm{~m}$ includes abundant tracheids and granulate amorphous aggregates of degraded material. Spores are abundant in relation to pollen grains. The overlying layers $(94.0-110.0 \mathrm{~m})$ are very 

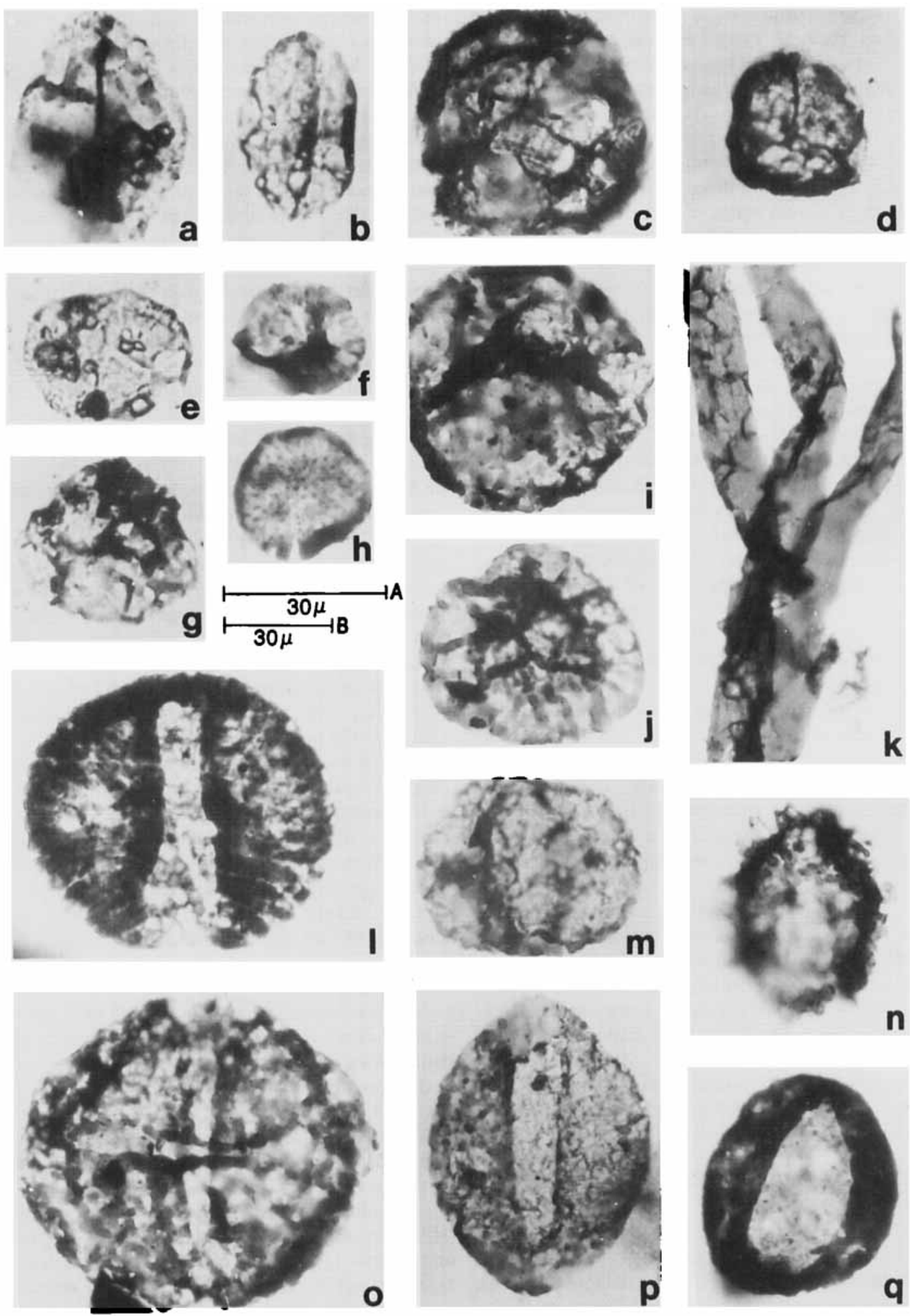
poorly productive, thus Triadispora spp., although common, are mostly identifiable only to generic level.

The palynological record above $94.0 \mathrm{~m}$ (up to $161.0 \mathrm{~m}$ ) is rather sparse. In addition to the samples reported in the range chart (Fig. 14a), a number of barren samples has been prepared from this part of the section. A few samples with reasonably well preserved palynomorphs occur between 161.0 and $176.0 \mathrm{~m}$. The highest occurrence of Echinitosporites iliacoides and the only record of the genus Retisulcites in sample 27 , between 161.0 and $167.0 \mathrm{~m}$, is evidence for a latest Ladinian age. Otherwise no important change is apparent at this level.

The assemblages immediately above (167.0, $168.0 \mathrm{~m}$ and sample 28 between 168.0 and $170.0 \mathrm{~m}$ ) are considered to represent the lower part of the Carnian ('Assemblage D-F' of Hochuli et al. 1989). Aulisporites astigmosus, a typical Carnian form, has been recorded only in sample 28. Illinites chitonoides, which is present in all productive samples and is believed to have an extinction level in the Early Carnian, has its highest occurrence at $168.0 \mathrm{~m}$. Hochuli et al. report it in 'Assemblage $F$ ' from the base of the Tschermakfjellet Formation in Spitsbergen. On the basis of the stratigraphic position of the interval we would therefore suggest an Early Carnian age. There is no positive palynological evidence for a closer dating of this interval in which the organic residues are dominated by coarse wood debris and poorly preserved palynomorphs.

The productive samples between 170.0 and
193.0 m contain a rather restricted Carnian assemblage and several samples from this interval proved to be barren of palynomorphs. There is no evidence for an age younger than Carnian in this uppermost part of the Skuld Formation.

Acritarchs are rarer in the Skuld Formation than in the Urd Formation, and are virtually absent in some samples, mainly between 103.5 and $124.0 \mathrm{~m}$. Records of the cenobial alga Plaesiodictyon mosellanum from $80.0 \mathrm{~m}$ and in sample 30 from near the top of the Skuld Formation reflect an influx from a fresh or brackish water environment. The discontinuous record of this species might also be a preservational feature due to the fragile nature of this palynomorph.

\section{Climate and plant geography}

The Triassic floras of land areas close to Bjørnøya and Spitsbergen are so far known only through their pollen and spores. Though poorly preserved, the palynoflora from Bjørnøya therefore warrants some palaeogeographic considerations. Reconstructions of Late Permian and Triassic floras in the Arctic are few. Wang Ziqiang (1985, fig. 2) shows a Eurasian arid province extending into northern China, distinct from the Angaran floras to the north, but does not consider the Canadian Arctic or the Svalbard region. Jacobsen \& Van Veen (1984), comparing conditions on the shelf along northern Norway, discussed the general European pattern of a humid Ladinian and a drier Carnian climate, as clearly expressed by the palynology in Haltenbanken. There is an increase

Fig. 15. Selected palynomorphs from the Urd and Skuld Formations. Enlargement Figs. a-h. j, l-n approximately $\times 750$ (scalc A). Figs. i, k, o-q approximately $\times 500$ (scale B). Sample numbers refer to Fig. 14a. Stage coordinates refer to Leitz Diaplan microscope at IKU, Trondheim. The PMO no. refers to the type collection of Palcontologisk Museum, Oslo, where the slides are stored

a Aratrisporites spp. Sample 4.1 m PMO $120791: 24$. 7-98.6

b Pretricolpipollenites Sample 6.0 m PMO 120 792:34.3-114.1

c Densoisporites playfordii Sample 49.0 m PMO 120 793: 16.7-98.8

d Densoisporites nejburgii Sample 49.0 m PMO $120793: 33.5-99.9$

e Proprisporites pococki Sample 1.2 m PMO 120 794:32.6-113.2

f Rewanispora vermiculata Samplc 0.7 m PMO 120 795:41.4-11.8

g Bhardwajispora labichensis Sample 56.5 m PMO 120 803:S 6036

h Micrhystridium spp. Sample 1.2 m PMO 120 794:25.0-11.0

i Punctatisporites fungosus Sample 18.0 m PMO $120796: 25.5-110.6$

j Staplinisporites caminus Sample 94.0 m PMO 120 797:21.4-92.6

k 'Fungal remain type 1' Sample 29.0 m PMO 120 798:21.9-109.2

1 Schizaeoisporites worsleyi Sample 67.0 m PMO $120799 ; 22.9-112.4$

m Triadispora sp. Sample 167.0 m PMO 120 800:22.6-113.4

n Echinitosporites iliacoides Sample 85.5 m PMO 120801 : 13.2-110.3

o Staurosaccites quadrifidus Sample 94.0 m PMO 120 797:30.0-107.8

p Chasmatosporites major Sample 167.0 m PMO 120 800:22.8-113.2

q Chasmatosporites apertus Sample 85.5 m PMO 120 802:27.4-95.5 

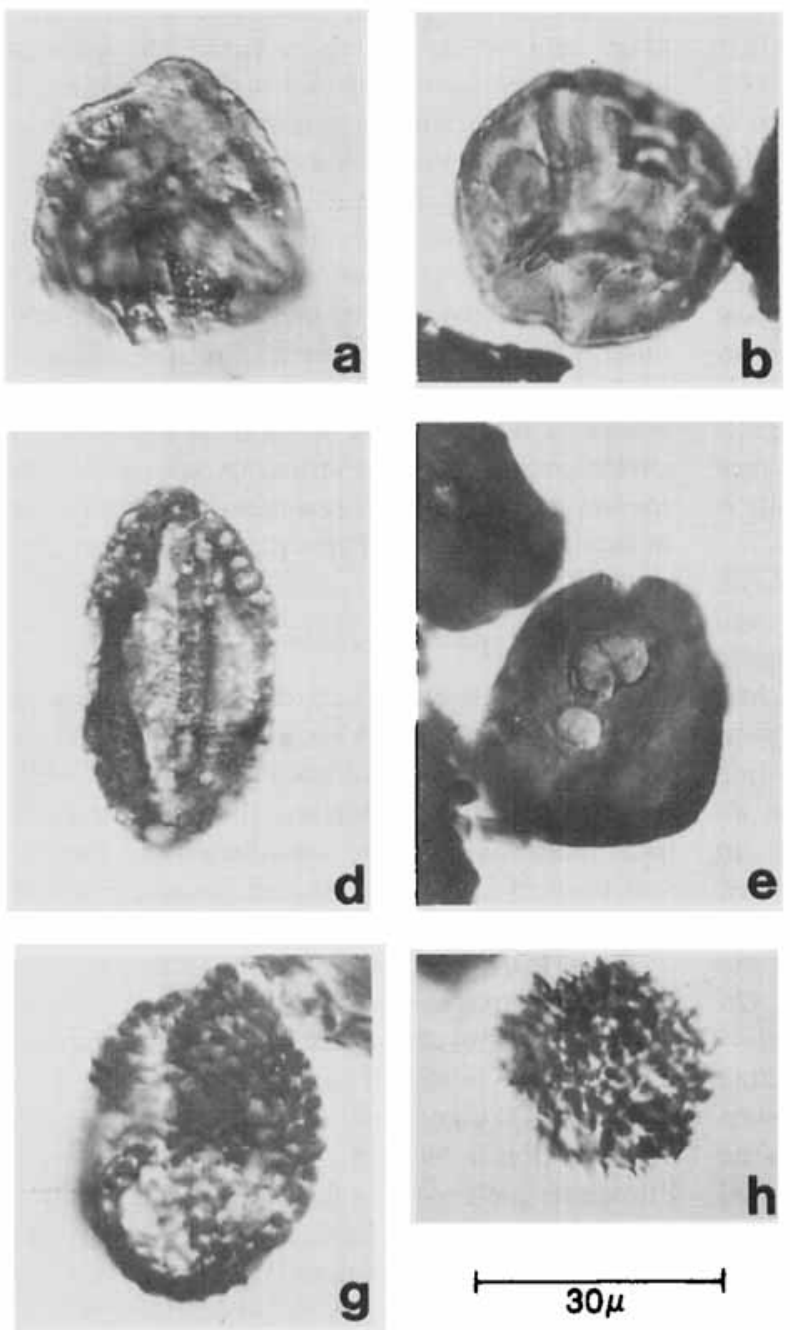

g

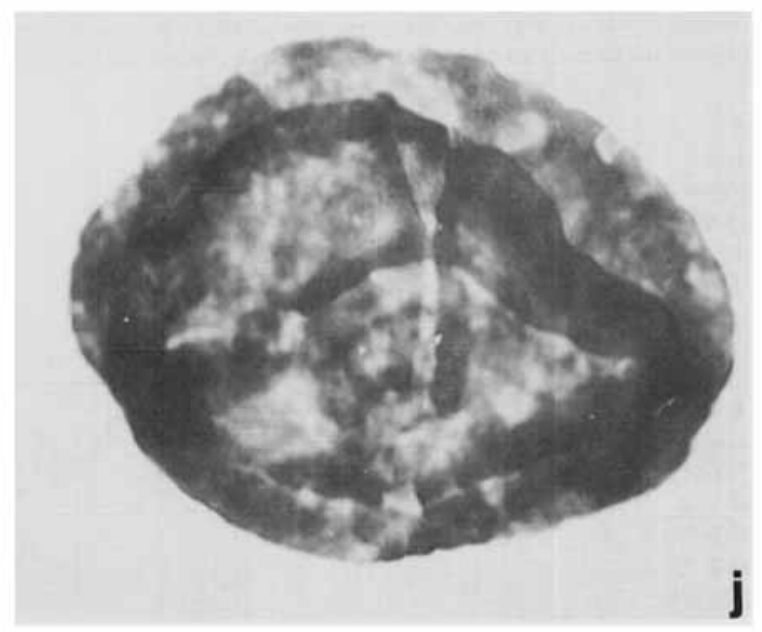

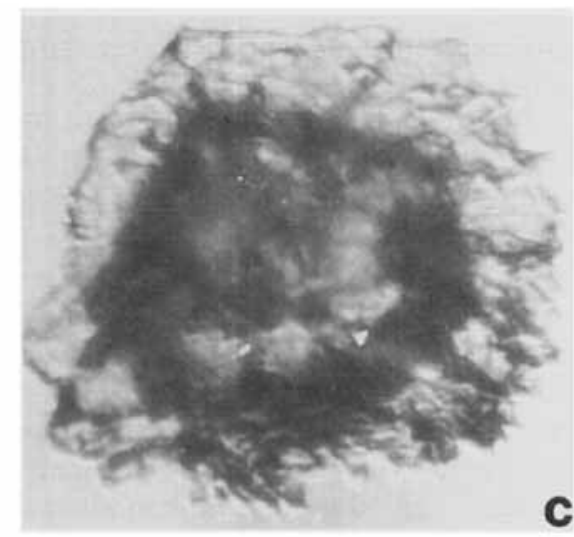
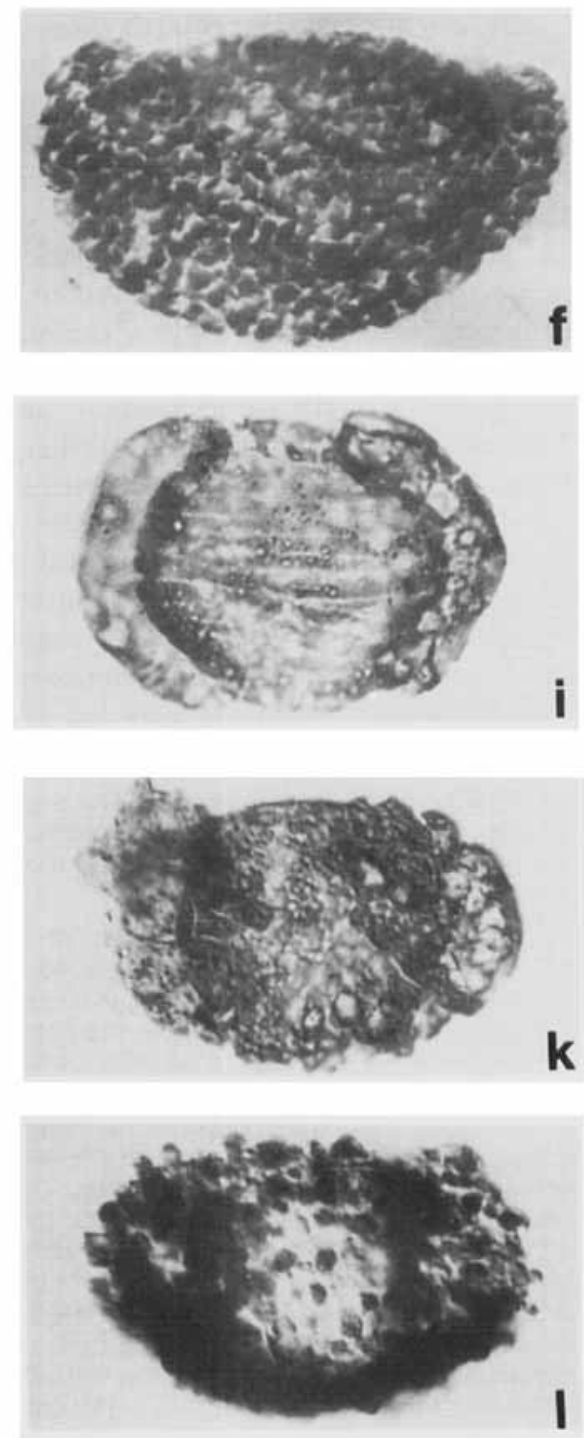
in humidity during the Carnian, which they found less evident in assemblages from the more temperate region of Troms. The Triassic palynomorph assemblages of the Barents Sea region, including Bjørnøya, would, on this basis, be expected to be related to the temperate conditions of a humid Russian province.

Early Triassic palynofloras in Bjørnøya are easily recognized and compared worldwide on the basis of their rich content of trilete cavate spores like Densoisporites spp., Lundbladispora spp. and Kraeuselisporites spp. (Fig. 14a). The spores were produced by an ecologically specialized group of pteridophytes, Pleuromeia spp., that dominated coastal areas. They were replaced by lycopsids that produced cavate monolete spores, Aratrisporites spp., a group that was well established earlier, but which became abundant in the Smithian of Bjørnøya and Svalbard (Hochuli et al. 1989), as well as in Arctic Canada (Fisher 1979). This early establishment contradicts their known appearance in more southern latitudes, and supports the idea that more humid, temperate climates developed in the Arctic when drier conditions unfavourable for the Aratrisporites group persisted in the south.

Another characteristic feature of most of the Urd Formation in Bjørnøya is the abundance of fungal hyphae ('Fungal remains type 1' of Hochuli et al. 1989), reflecting a local humid environment. The same feature has also been recorded (Hochuli et al. 1989) in Spitsbergen, and seems a general feature in Smithian deposits of the Barents Sea area.

The Late Ladinian of the Skuld Formation in Bjørnøya is dated on the basis of Echinitosporites iliacoides, which is stratigraphically restricted in the Germanic and Alpine regions (Visscher \& Brugman 1981). The fairly well preserved paly. nological assemblages are distinguished by the abundance and variety of gymnosperm pollen, such as Alisporites microreticulatus and Vitreisporites pallidus that are common in the other regions, but there are important differences. Pollen, including Triadispora verrucata, Staurosaccites quadrifidus and Chasmatosporites spp., present at this level are believed not to appear until the Carnian in more southern provinces.

The number of pteridophyte spores, among them Leschikisporis sp., increases dramatically towards the labyrinthodont bed, probably as a result of proximity to a contemporaneous shoreline, and shows that there was a rich vegetation partly dependent on humid conditions close to Bjørnøya. There are strikingly few members of the dry climate indicators (Visscher \& Van der Zwan 1981) of the Circumpolles group which are so characteristic in the Ladinian and Carnian of southern areas (Van der Eem 1983; Blendinger 1988). This would support the inference of a temperate humid climate in the Ladinian.

The palynology of the Carnian deposits in Bjørnøya (Fig. 14a) compared with that of the Late Ladinian suggests that there were no dramatic environmental changes. The large number of pteridophyte spores and the near absence of the Circumpolles group support the continuation of fairly humid conditions in the area.

\section{Ages and correlations}

On the basis of macrofossils and palynology the following ages may be assigned to the Triassic succession:

The lowest three metres of the Urd Formation contain representatives of palyno-assemblage ' $\mathrm{O}$ ' of Hochuli et al. (1989), which is also found in

Fig. 16. Selected palynomorphs from the Skuld Formation. Enlargement approximately $\times 750$ (scale bar). Sample numbers refer to Fig. 14a. All specimens have stage coordinates referring to Leitz Ortholux II microscope in the Esso Laboratories, Bordeaux. The slides are stored in the Esso Laboratories, Bordeaux

a Zebrasporites kahleri Sample BJ 27:31.7-102.0

b Camarozonosporites rudis Sample BJ 27:44.2-112.2

c Semiretisporis sp. Sample BJ 27:36.7-95.0

d Ovalipollis pseudoalaius Sample $66.0 \mathrm{~m}: 26.4-100.2$

e Aulisporites astigmosus Sample BJ 28:28.2-93.2

f Protodiploxypinus ornatus Sample BJ 27:26.0-105.8

g Retisulcites sp. Sample BJ 27:29.0-95.3

h Gibeosporites lativerrucosus BJ 27:25.3-100.3

i Striatoabieites sp. A Sample $66.0 \mathrm{~m}: 21.0-110.2$

j Illinites chitonoides Sample BJ 27:42.2-96.7

k Triadispora verrucata Sample $66.0 \mathrm{~m}: 26.2-109.4$

I Protodiploxypinus sp. cf. P. ornatus Sample BJ 27:43.0-109.7 
the Vardebukta Formation of Spitsbergen in beds of Dienerian age. An Early Triassic transgression farther southeast in the Hammerfest Basin is also assigned to the Dienerian (Jacobsen \& Van Veen 1984), and may thus correlate with that transgression in Bjørnøya.

The middle and upper parts of the Urd Formation contain the ammonoid Euflemingites sp. of early Smithian age, and the presence of ?Arctoceras blomstrandi close to the top of the formation shows that this whole interval was deposited in Smithian times. The presence of palyno-assemblage ' $\mathrm{N}$ ' supports this age. These beds correlate with the lower parts of the Tvillingodden Formation and Sticky Keep Member of Spitsbergen.

The Verdande Bed contains no identifiable macrofossils, but sparse palynomorphs suggest an Early Anisian or older age. Abundant phosphate nodules occur in the Bravaisberget Formation and Botneheia Member and their presence in the Verdande Bed was the main basis for its lithostratigraphic correlation with Middle Triassic beds of Spitsbergen, and the proposal that all or most of the Spathian is missing in Bjørnøya (Pchelina 1972).

The lower beds of the Skuld Formation contain palynomorphs representative of palyno-assemblage ' $G$ ', or possibly ' $\mathrm{H}$ ', of Hochuli et al. (1989), both indicating a Late Ladinian age. No Anisian or typical Early Ladinian palynomorphs were recorded. The Verdande Bed may, therefore, comprise a remanié deposit of sediments of Middle Triassic (Anisian) or possibly Early Triassic (Spathian) age. A major depositional break, with erosion during the Anisian and Early Ladinian, is probable.

Approximately $40 \mathrm{~m}$ below the top of the Skuld Formation the ammonoid Daxatina canadensis confirms the presence of latest Ladinian sediments (Böhm 1903; Tozer \& Parker 1968). The palynomorph assemblages below this level, although poorly preserved, resemble the Late Ladinian palyno-assemblage ' $G$ ', and samples from the succeeding $40 \mathrm{~m}$ contain some components of the early Carnian (palyno-assemblage ' $F$ to $D$ '). There are strong lithological similarities between the grey shales, with abundant red weathering siderite nodules, of the Skuld Formation and the Tschermakfjellet Formation on Spitsbergen. The impure sandstones of the Skuld Formation are also similar to lithologies reported by Mørk et al. (1982) from the De Geerdalen
Formation on Spitsbergen. In Spitsbergen the transition from the Bravaisberget Formation Botneheia Member to the Tschermakfjellet Formation at the base of the Kapp Toscana Group is now regarded as being around the Ladinian Carnian transition (Korchinskaya 1982; Mørk et al. 1989). The continuous presence of lithologies that are similar to those of the Tschermakfjellet Formation through the major part of the Skuld Formation indicates that the change from mature to immature mineralogy took place earlier in Bjørnøya than in the other Svalbard islands.

\section{Depositional cycles}

Mørk et al. (1989) have described transgressiveregressive cycles for Triassic sequences in the Arctic, and demonstrated that most are correlatable from the Sverdrup Basin through Svalbard to the Barents Sea. The incomplete succession of Bjørnøya follows the same cycle pattern, but shows important differences.

The marked change in sedimentation pattern, from fault controlled in the Carboniferous-early Permian to tectonically stable in the late PermianTriassic, has been recognized for the Svalbard Archipelago by Steel \& Worsley (1984) and described from Bjørnøya by Worsley et al. (in press). The break in sedimentation between the Miseryfjellet Formation and the Urd Formation represents a long period of time, and the basal (Griesbachian) transgression recognized in most other Arctic areas (Mørk et al. 1989) does not seem to have affected Bjørnøya.

Dienerian cycle. - The basal sandstone unit at Bjørnøya, which is only 1 to $2 \mathrm{~m}$ thick, contains abundant clasts from the underlying formation. and may be regarded as the initial deposit of the transgressive Triassic clastic sequence. At Sørkapp Land, on southern Spitsbergen, a transgressive basal conglomerate (the Brevassfjellet Bed), regarded as Dienerian in age by Birkenmajer (1977), overlies both Hecla Hoek basement and Palaeozoic rocks on the SørkappHornsund High (Worsley \& Mørk 1978; Mørk et al. 1982). The Dienerian transgression of Bjørnøya is thus contemporaneous with the last part of the early Triassic transgression in the Svalbard Archipelago and in the Hammerfest Basin as reported by Jacobsen \& Van Veen (1984). The sedimentation initiated in the 
Dienerian continued during the next transgression, apparently with deposition in the same facies.

Smithian cycle. - Around $20 \mathrm{~m}$ above the base of the section the darker sediments contain poorly preserved ammonoids that are common in beds referred to the Smithian elsewhere in Svalbard. The colour change in the basal part of the Smithian beds is interpreted as a result of reduced sedimentation rates with a relative increase of the organic content due to a major highstand. This event can also be recognized at the base of the Tvillingodden Formation and the Sticky Keep Member elsewhere in Svalbard (Mørk et al. 1982), and may also be traced to the Sverdrup Basin and other Arctic areas (Mørk et al. 1989). The Smithian palyno-assemblage ' $\mathrm{N}$ ' of Hochuli et al. (1989) was recorded from the $6.0 \mathrm{~m}$ level upwards in the Urd Formation.

The upper few metres of the Urd Formation include several silty dolomitic beds with a few poorly preserved fossils. These beds have been treated in detail by Pchelina (1972), who regarded them as a condensed interval, including probable periods of non-deposition. Pchelina reported the presence of the ammonoid ?Arctoceras blomstrandi in these beds; this species is common in Smithian beds elsewhere in Svalbard (Korchinskaya 1982), where the age is confirmed by palynomorphs. If we accept a Middle Triassic age for the Verdande Bed (see below), it seems that large parts of the Spathian are missing on Bjørnøya or represented by a strongly condensed section.

Anisian-Ladinian sedimentation and erosion.-The poor palynological evidence defining the age of the phosphate nodules of the Verdande Bed as older than Middle Anisian suggests, with the lithological correlation with nodule bearing Middle Triassic sediments on Spitsbergen, that these rocks formed in the Early Anisian. Early Ladinian transgressions are reported in other Arctic regions (Mørk et al. 1989) and this may have resulted in the deposition of the phosphate nodules in Bjørnøya. Alternatively, as the oldest beds of the Skuld Formation are probably of Late Ladinian age, the nodules may not have been deposited before that time as a basal remanie conglomerate for the Skuld Formation. So far, no information is available regarding the thickness of the sediments removed during the formation of the remanié conglomerate. However, the heterogeneous grain composition and the lithoclasts in the nodules indicate that they represent a variety of facies associations. Possible hiatuses, both in the Spathian and the lowermost part of the Middle Triassic, may indicate a complex local subsidence history for this part of the Barents Shelf.

Late Ladinian cycle. - The dating by palynology of the basal beds of the Skuld Formation as Late Ladinian and the presence of the latest Ladinian ammonoid Daxatina canadensis some $40 \mathrm{~m}$ below the top of the Skuld Formation put some constraints on the interpretations as compared with the cycle development elsewhere in the Arctic. Nearly one hundred metres of sediments may have been deposited rapidly, possibly as a result of sediment influx from the east. The change in the mineralogy from the Urd Formation to the Skuld Formation is similar to those observed between the Sassendalen and the Kapp Toscana Groups elsewhere in Svalbard. On Spitsbergen this transition is thought to occur close to the Ladinian-Carnian boundary (Korchinskaya 1982).

Carnian cycle. - The upper part of the Skuld Formation forms a sequence grading from dark shale to thickly bedded sandstones. The consistent Carnian evidence from palynology and macrofossils supports an interpretation of this part of the succession as representing a Carnian transgressive-regressive cycle.

\section{Regional thickness variations}

The $200 \mathrm{~m}$ of Triassic rocks are at present the youngest deposits on Bjørnøya. As deduced from the maturation level of the organic content (Bjorøy et al. 1983), they were at one time overlain by two to three $\mathrm{km}$ of younger deposits, which may have been of any age from the late Triassic to Tertiary. On Spitsbergen the thickness of the Sassendalen Group varies from 120 to $700 \mathrm{~m}$ and the Kapp Toscana Group ranges from 80 to more than $475 \mathrm{~m}$ (Mørk et al. 1982).

Thickness variation in offshore areas is considerable, with highs (Loppa High and parts of the Stappen High) having only a thin Mesozoic sediment cover, while the basinal successions (e.g. in the Bjørnøya Basin) may comprise up to $10 \mathrm{~km}$ of Mesozoic rocks (Faleide et al. 1984). In the Hammerfest Basin more than two $\mathrm{km}$ of 
Triassic sediments are present (Worsley et al. 1988).

The thickness of the Sassendalen Group on Bjørnøya is in the same range as on the SørkappHornsund High. However, while Lower Triassic sediments are thin on the Sørkapp-Hornsund High, they comprise all of the Urd Formation on Bjørnøya. The lower part of the Middle Triassic succession, in contrast, is relatively thick on the Sørkapp-Hornsund High but is only represented by the Verdande Bed on Bjørnøya. These opposite relationships between two positive features, the Sørkapp-Hornsund and Stappen Highs, suggest that they have different uplift and subsidence histories. As indicated on Sørkappøya (south of Spitsbergen), with at least $220 \mathrm{~m}$ exposed of the Sassendalen Group, they may have been separated by a basin.

The Skuld Formation correlates with the lower part of the Kapp Toscana Group elsewhere in Svalbard, where the Tschermakfjellet and Austjøkelen Formations are around $60 \mathrm{~m}$ thick. However, there is a gradual transition from these formations to the De Geerdalen Formation and the combined thickness of the group exceeds $475 \mathrm{~m}$ in eastern Svalbard, while on the SørkappHornsund High it is only $50 \mathrm{~m}$ thick.

These thickness variations conflict with the suggestion by Faleide et al. (1984) that the Stappen High (with Bjørnøya) is connected to the SørkappHornsund High. The general structural trend to NNW-SSE oriented lineaments observed in Svalbard and Bjørnøya also contradicts that view, and may indicate that a sub-basin, or an area with greater subsidence, separated these two areas during deposition of the Sassendalen Group.

\section{Summary}

Only a few of the Triassic transgressions noted by Mørk et al. (1989) from the Barents Sea, Svalbard and the Sverdrup Basin can be recognized on Bjørnøya, namely those of Dienerian, early Smithian, ?Anisian and Carnian age. Even in these sequences normal transgressive-regressive cycles were not fully developed, as sedimentation seems to have been repeatedly interrupted and parts of the succession eroded, following local uplift.

Important hiatuses occur in the Griesbachian, Spathian, ? earliest Anisian and late Anisian-early Ladinian sequences. The development of these truncated cycles and the abundant hiatuses is consistent with Bjørnøya's location on a separate tectonic block with a different subsidence and uplift history from Spitsbergen and the adjacent Barents Shelf areas, although the general pattern of sedimentation on Bjørnøya is similar to that observed throughout the Arctic.

Acknowledgements. - The work is part of the IKU Arctic (icoprogram, which is economically supported by A/S Norske Shell, BP Petroleum Development (Norway) Ltd., Elf Aquitaine Norge A/S, Esso Norge a.S. Fina Exploration Norway Utenl. A/S, Mobil Exploration Norway Inc., Norsk Agip A/S. Norsk Hydro a.s., Phillips Petroleum Co. Norway, Saga Petroleum a.s. and Statoil. We also acknowledge the permission to include the results from a palynological project carried out for Esso Norge a.s. We would like to thank Arne W. Forsberg and David Worsley for cooperation in the field and for numerous discussions. Fossils have been identified by Wolfgang Weitschat (ammonoids), Franz-Josef Lindemann (fish remains) and Jack Babcock (dasycladacean algae); their advice is gratefully acknowledged. The manuscript benefits from comments from David Worsley, Geoffrey Warrington and Stefan Piasecki. Drawings are by Ingrid Brandslet.

\section{References}

Andersson, J. G. 1900: Über dic Stratigraphic und Tektonik der Bären Insel. Bull. Geol. Inst. Unio. Uppsalu 4, 243-280.

Balme, B. E. 1980: Palynology of Permian-Triassic boundary beds at Kap Stosch, East Greenland. Meddelelser om Gronland 200 (6), 1-37.

Birkenmajer, K. 1977: Triassic sedimentary formations of the Hornsund area, Spitsbergen. Studia Geologica Polonica 2 (8), 7-74.

Bjorøy, M., Mørk, A. \& Vigran, J. O, 1983: Organic gcochemical studics of the Devonian to Triassic succession on Bjørnøya and the implications for the Barents Shelf. Pp. 49 59 in Bjorøy, M. el al. (cds.): Advances in Organic Geochemistry 1981. John Wilcy \& Sons Lid.

Bjarke, T. \& Dypvik, H. 1977: Sedimentological and palynological studies of Upper Triassic-Lower Jurassic sediments in Sassenfjorden. Spitsbergen. Norsk Polarinstitut Árbok $1976,131-150$.

Bjærke, T. \& Manum, S. B. 1977: Mcsozoic palynology of Svalbard-1. The Rhactian of Hopen, with preliminary report on the Rhaetian and Jurassic of Kong Karls Land. Norsk Polarinstitutt Skrifter 165, 1-48. 9 pls.

Blendinger, E. 1988: Palynostratigraphy of the Late Ladinian and Carnian in the Southeastern Dolomites. Review of Palaeobotany and Palynology 53, 329-348.

Buchan, S. H., Challinor, A., Harland, W. B. \& Parker, J. R. 1965: The Triassic stratigraphy of Svalbard. Norsk Polarinstitut Skrifter 135.95 pp.

Böhm, J. 1899: Über Triastossilien der Bären-Insel. Zeitschrift der geologischen Gesellschaft, Berlin B.51, 325-326.

Böhm, J. 1903: Über die obertriadische Fauna der Bäreninsel. Kungliga Suenska Vetenskaps-Akademiens Handlingar 37, 176.

Falcide, J. I., Gudlaugsson, S. T. \& Jacquart. G. 1984: Evolution of the western Barents Sea. Marine Petroleum Geology $1,123-150$.

Fisher, M. J. 1979: The Triassic palynofloral succession in the 
Canadian Arctic Archipelago. American Association of Stratigraphic Palynologists Contribution Series 5B, 83-100).

Hochuli, P. A., Colin, J. P. \& Vigran, J. O. 1989: Triassic biostratigraphy of the Barents Sca area. Pp. 131-153 in Collinson. J. D. (ed.): Correlation in Hydrocarbon Exploration. Norwegian Petroleum Society. Graham \& Trotman Ltd.

Horn, G. \& Orvin, A. K. 1928: Geology of Bear Island. Skrifter om Sualbard og Ishavet 15, 1-152, 8 pls. 1 map.

Jitcobsen, V. \& Van Veen, P. 1984: The Triassic offshore Norway north of $62^{\circ} \mathrm{N}$. Pp. 317-328 in Spencer, A. M. et al. (cds.): Petroleum Geology of the North European Margin. Norwegian Petrolcum Society. Graham \& Trotman Ltd.

Jansonius, J. 1962: Palynology of Permian and Triassic sediments, Peace River area. Western Canada. Palaeontographica Abt. B 110 (1-4), 35-95.

Jarosenko, O. P. \& Golubeva, L. P. 1981: Palynological charactcrization of lower Triassic deposits of the Timan-Pechora Province and contiguous regions. ANSSSR, Isvestija. Serija geologiceskaja 10,90-95 (in Russian)

Korchinskaya, M. V. 1982: Obyasnitelnava zapiska k stratigraficheskoy skheme mesozoya (trias) Svalbarda. (An explanatory note to the stratigraphic scheme of the Mesozoic (Trias) of Svalbard.) Min. Geol. USSR, NPO, 'Sevmorgeo', 40-99 (in Russian)

Krasilshchikov, A. A. \& Livshits, J. J. 1974: Tektonika ostrova Medvezy. (Tectonics of Bjørnøya). Geotektonika 4, 39-51.

Lowy, J. 1949: A labyrinthodont from the Trias of Bear Island, Spitsbergen. Nature 163, 1002.

Mørk, A.. Embry. A. F. \& Wcitschat, W. 1989: Triassic transgressive-regressive cyeles in the Sverdrup Basin, Svalburd, and the Barents Shelf. Pp. 113-130 in Collinson, J. D. (ed.): Correlation in Hydrocarbon Exploration. Norwegian Petroleum Socicty. Graham \& Trotman Ltd.

Mork, A., Knarud, R. \& Worsley, D. 1982: Depositional and diagenctic environments of the Triassic and Lower Jurassic succession of Svalbard. Pp. 371-398 in Embry, A. F. \& Balkwill, H. R. (cds.): Arctic Geology and Geophysics. Canadian Society of Petroleum Geologists Memoir 8.

Nathorst, A. G. 1910: Beiträge zur Geologic der Bären-Insel, Spitzbergens und des König Karl-Landes. Uppsala, Bull. (Geol. Inst. 10, 267-291.

Pchelina, T. M. 1972: Triassic deposits of Bjørnøya. Pp. 5-20 in Sokolov, V. N. \& Vasilievskaya, N. D. (cds.): Mesozoic deposits of Sialbard. S-20 NIIGA Leningrad (in Russian).

Smith, D. G., Harland, W. B. \& Hlughes, N. F. 1975: Gcology of Hopen, Svalbard. Geological Magazine 1/2, 1-23.

Steel, R. J. \& Worslcy, D. 1984: Svalbard's post-Caledonian strata. An atlas of sedimentational patterns and palacogeographic evolution. Pp. 109-135 in Spencer, A. M. et al. (cds.): Petroleum Geology of the North European Margin. Norwegian Petrolcum Society. Graham \& Troiman Ltd
Stensiö, E. 1925: Triassic fishes from Spitsbergen. Part I1. Kungliga Suenska Vetenskaps-Akademiens Handlingar Serie 3(2), 1-261

Tozer, E. T. 1961: Triassic stratigraphy and faunas, Queen Elizabeth Islands. Arctic Archipclago. Memoir Geological Survey of Canada 361, 1-116.

Tozer, E. T, 1967: A standard for Triassic Time. Bulletin Geological Survey of Canada 156. 1-103.

Tozer, E. T. \& Parker, J. R. 1968: Notes on the Triassic biostratigraphy of Svalbard. Geological Magazine 105. 526542 .

Utting, J. 1985: Preliminary results of palynological studies of the Permian and lowermost Triassic sediments. Sabine Peninsula, Melville Island. Canadian Arctic Archipclago. Geological Survey of Canada. Current Research. Paper 85 $1 B$, part $B, 231-238$.

Utting, J. 1989: Preliminary palynological zonation of surface and subsurface sections of Carboniferous. Permian and lowest Triassic rocks, Sverdrup Basin, Canadian Arctic Archipclago. Geological Survey of Canada, Curren Research. Paper 89. IG. part G, 233-240.

Van der Eem, J. G. L. A. 1983: Aspects of Middle and Late Triassic palynology. 6. Palynological investigations in the Ladinian and Lower Karnian of the western Dolomites, Italy. Review of Palueobotany and Palynology 39, 189-300.

Visscher, H. \& Brugman. W. A. 1981: Rangcs of selected palynomorphs in the Alpine Triassic of Europe. Review of Palaeobotany and Palynology 34, 115-128.

Visscher, H. \& Van der Zwan. C. J. 1981: Palynology of the circum Mediterranean Triassic of western Europe. Geologische Rundschau 70, 625-634.

Wang Ziqiang 1985: Palaeovegetation and plate tectonics: Palaeophytogeography of North China during Permian and Triassic times. Palaeogeography, Palaeoclimatology, Palaeoecology 49, 25-45.

Worsley, D., Agdestein, T., Gjelberg, J., Kirkemo, K. \& Steel R. J. in press: Late Palaeozoic basinal evolution and stabilization of Bjørnøya - implications for the Barents Shelf. American Association of Petroleum Geologists Bulletin.

Worslcy, D. \& Mork, A. 1978: The Triassic stratigraphy of southern Spitsbergen. Norsk Polarinstitut Ârbok 1977. 4360 .

Worsley, D. \& Edwards, M. B. 1976: The Upper Palacozoic succession of Bjørnøya. Norsk Polarinstitut Arbok 1974, 1734

Worslcy, D., Johansen, R. \& Kristensen, S. E. 1988: The Mesozoic and Cenozoic succession of Tromsøflaket. Pp. 42 65 in Dalland, A., Worslcy, D. \& Ofstad, K. (cds.): A lithostratigraphic scheme for the Mesozoic and Cenozoic succession offshore mid-and northern Norway. Norwegian Petroleum Directorate Bulletin 4. 
